\title{
Proteomic-Based Biosignatures in Breast Cancer Classification and Prediction of Therapeutic Response
}

\author{
Jianbo He, ${ }^{1,2}$ Stephen A. Whelan, ${ }^{3}$ Ming Lu, ${ }^{4}$ Dejun Shen, ${ }^{5}$ Debra U. Chung, ${ }^{2}$ \\ Romaine E. Saxton, ${ }^{1,2}$ Kym F. Faull, ${ }^{6}$ Julian P. Whitelegge, ${ }^{6}$ and Helena R. Chang ${ }^{1,2,7}$ \\ ${ }^{1}$ Gonda/UCLA Breast Cancer Research Laboratory, David Geffen School of Medicine, University of California at Los Angeles, \\ Los Angeles, CA 90095, USA \\ ${ }^{2}$ Department of Surgery, David Geffen School of Medicine, University of California at Los Angeles, Los Angeles, CA 90095, USA \\ ${ }^{3}$ Cardiovascular Proteomics Center, Center for Biomedical Mass Spectrometry, Boston University School of Medicine, Boston, \\ MA 02118, USA \\ ${ }^{4}$ Department of Medicine, David Geffen School of Medicine, University of California at Los Angeles, Los Angeles, CA 90095, USA \\ ${ }^{5}$ Department of Pathology, Beth Israel Deaconess Medical Center, Harvard Medical School, Boston, MA 02215, USA \\ ${ }^{6}$ Pasarow Mass Spectrometry Laboratory, Semel Institute and Department of Psychiatry and Biobehavioral Science, \\ David Geffen School of Medicine, University of California at Los Angeles, Los Angeles, CA 90095, USA \\ ${ }^{7}$ Revlon/UCLA Breast Center, David Geffen School of Medicine at UCLA, 200 UCLA Medical Plaza, B265, Los Angeles, \\ CA 90095, USA
}

Correspondence should be addressed to Helena R. Chang, hchang@mednet.ucla.edu

Received 22 June 2011; Accepted 12 August 2011

Academic Editor: David E. Misek

Copyright (๑) 2011 Jianbo He et al. This is an open access article distributed under the Creative Commons Attribution License, which permits unrestricted use, distribution, and reproduction in any medium, provided the original work is properly cited.

Protein-based markers that classify tumor subtypes and predict therapeutic response would be clinically useful in guiding patient treatment. We investigated the LC-MS/MS-identified protein biosignatures in 39 baseline breast cancer specimens including 28 HER2-positive and 11 triple-negative (TNBC) tumors. Twenty proteins were found to correctly classify all HER2 positive and 7 of the 11 TNBC tumors. Among them, galectin-3-binding protein and ALDH1A1 were found preferentially elevated in TNBC, whereas CK19, transferrin, transketolase, and thymosin $\beta 4$ and $\beta 10$ were elevated in HER2-positive cancers. In addition, several proteins such as enolase, vimentin, peroxiredoxin 5, Hsp 70, periostin precursor, RhoA, cathepsin D preproprotein, and annexin 1 were found to be associated with the tumor responses to treatment within each subtype. The MS-based proteomic findings appear promising in guiding tumor classification and predicting response. When sufficiently validated, some of these candidate protein markers could have great potential in improving breast cancer treatment.

\section{Introduction}

Chemotherapy has long been used to treat all types of cancer. Although survival benefits from adjuvant systemic chemotherapy in breast cancer have been thoroughly documented [1], success is not uniform with many still dying after the initial chemotherapy. The unpredictable tumor response to chemotherapy in any given patient and the significant toxicity manifested in all demand a better strategy for delivering cancer therapy.

In selective subtypes of breast cancer, therapies targeting specific signal transduction and/or metabolic pathways have been successful. For example, Herceptin for HER2/neu positive breast cancer $[2,3]$ and poly(ADP ribose) polymerase (PARP) inhibitors for triple-negative breast cancer with defective DNA-repair $[4,5]$ are among the recent successes of targeted therapy. The success of target therapy has led to an explosion of interest in developing tailored systemic therapy.

Breast cancer is a heterogeneous disease molecularly, histologically, and clinically. Clinical outcomes from the same treatment vary widely even among patients with tumors of identical stage and histology. Breast cancers developed from an accumulation of genetic alterations may partially explain the differences observed including tumor responses 
to anticancer agents [6]. Recently gene expression analysis has identified five subtypes of breast cancer which overlaps with clinical tumor classification according to the expression of three biomarkers, estrogen receptor (ER), progesterone receptor (PR), and epidermal growth factor receptor 2 (HER2). Clinically these three markers are prognostically and therapeutically important in guiding treatment selection [7-10]; however, they do not fully reflect the complexity and heterogeneity of breast cancer and do not always predict the outcome of the treatment. For example, Herceptin as a single agent or in combination with chemotherapy has been shown to reduce recurrent disease and to save lives in patients with HER2-positive breast cancer, yet a significant number of HER2 overexpression tumors do not respond to the treatment [11]. Additional molecular targets are expected to improve tailored treatment in the future.

Proteomics has been employed in recent years to identify new disease-related biomarkers for cancer diagnosis and implementation of tailored treatment [12-15]. The tumor proteomes representing a global protein expression of cancer may provide new insights into the molecules that govern the dynamic cellular activities of tumor cells. Therefore, we choose to study breast tumor protein signatures in breast cancer classification and in predicting tumor response to treatment.

Previously we used SELDI mass spectrometry to profile tumor response to neoadjuvant treatment and found that significant $\mathrm{m} / \mathrm{z}$ profile differences existed between cancers of nonresponders (tumor regression rate $\leq 25 \%$ ) and others (tumor regression rate $>25 \%$ ) [16]. In this current study we have applied the LC-MS/MS technology to study the breast cancer proteomes in human tissues and identify unique proteins that may have the potential to separate two subtypes of breast cancer (TNBC versus HER2+) and to predict drug responses within each subtype.

\section{Materials and Methods}

2.1. Collection of Breast Tumor Tissues and Classification of Response. Breast tumors were collected, processed, and banked as previously described [16]. This study was approved by the UCLA institutional review board (IRB). Tumors from 39 consented patients with locally advanced breast cancer were collected from a neoadjuvant clinical trial [17]. Eleven were triple-negative breast tumors (TNBC, ER/PR-/HER2-), and 28 were HER2-positive tumors (HER2+). The tumor specimens were uniformly collected according to a standard operating procedure established in our laboratory. Baseline tumor specimens were obtained by either core needle biopsy or surgical biopsy before starting the neoadjuvant Taxotere/Carboplatin/ \pm Herceptin treatment $(\mathrm{TC} \pm \mathrm{H})$. Evaluation of tumor response to the treatment was measured both by pathologic examination of surgically removed tissue and by clinical assessment including physical examination and/or imaging studies. The pathological response of the tumor was reported as either pathologically complete response ( $\mathrm{pCR}$ ) or having residual tumor. Because a baseline tumor size by pathologic evaluation was not possible in patients receiving neoadjuvant treatment, the clinically or imaging-measured tumor size prior to chemotherapy was used as the baseline tumor size. Pathological assessment after chemotherapy including tumor size, lymph node staging, and tumor biomarkers was performed on the specimen obtained from the definitive breast cancer surgery [16]. The tumor regression rate (TRR) was used to evaluate tumor response induced by neoadjuvant therapy, and it was calculated as follows: (baseline tumor size - residual tumor size)/baseline tumor size $\times 100 \%$, where the baseline tumor size was measured clinically, and the postchemotherapy residual invasive tumor size was measured pathologically. The tumor response was categorized into three groups: responders (TRR $>75 \%, \mathrm{R})$, intermediate responders $(25 \%<\mathrm{TRR} \leq 75 \%, \mathrm{IR})$, and nonresponders (TRR $\leq 25 \%$, NR).

\subsection{Protein Extraction and Abundant Protein Depletion.} Protein extraction from tumors and depletion of abundant proteins from tumor lysates were performed as previously described [16]. Briefly, frozen tumors were homogenized in liquid nitrogen and suspended in 1\% Triton X-100. The samples were refrozen at $-80^{\circ} \mathrm{C}$ and thawed on ice twice. Following centrifugation $\left(10,000 \mathrm{~g}, 10 \mathrm{~min}, 4^{\circ} \mathrm{C}\right)$, the supernatants were subjected to albumin and immunoglobulin depletion using an albumin and IgG removal kit (Amersham) as well as hemoglobin depletion using Ni-NTA magnetic agarose beads (Qiagen). Protein concentrations of each preparation were determined by the BioRad protein assays.

Because the blood proteins in the breast cancer tissue can cause significant ion suppression of lower abundance cancerrelated proteins/peptides which may mask ion signals of less abundant peptides with similar $\mathrm{M} / \mathrm{Z}$ ratios and retention times. In addition, the over presentation of serum proteins in the specimen may lower the amount of the cancer-related proteins available for LC-MS/MS analysis [18]. As a result, selected abundant serum proteins were depleted from the tissue extracts. Our preliminary test has shown more than 95\% albumin, IgG and hemoglobin were removed by the described method, and more meaningful proteins have been detected.

2.3. Trypsin Digestion. The dried protein samples were dissolved in $6 \mathrm{M}$ guanidine $\mathrm{HCl}$, reduced with DTT ( $5 \mathrm{mM}-$ $15 \mathrm{mM}$ ), and alkylated using $10 \mathrm{mM}$ iodoacetamide. Samples were then diluted with $\mathrm{NH}_{4} \mathrm{HCO}_{3}$ to lower guanidine $\mathrm{HCl}$ concentration $(1 \mathrm{M})$, mixed with trypsin $(1: 50 \mathrm{w} / \mathrm{w}$ ratio, sequencing grade, Promega) containing $50 \mathrm{mM}$ ammonium bicarbonate, and incubated at $37^{\circ} \mathrm{C}$ overnight. Samples were desalted by C18 Microspin columns (The Nest Group), and the eluates were dried in a vacuum centrifuge.

2.4. LC-MS/MS Analysis. Each digested and dried sample was prepared for LC-MS/MS analysis as previously reported [19]. Briefly the samples were redissolved in Buffer A $\left(\mathrm{H}_{2} \mathrm{O}\right.$ /acetonitrile/formic acid, 98.9/1/0.1, typically at $0.7 \mu \mathrm{g}$ protein $/ \mathrm{uL})$, and aliquots were injected $(5 \mu \mathrm{L})$ onto an 
in-house-prepared C18 trap. The retained materials were placed onto a reverse phase column (New Objective C18, $15 \mathrm{~cm}, 75 \mu \mathrm{M}$ diameter, $5 \mu \mathrm{m}$ particle size equilibrated in Buffer A) and eluted $(300 \mathrm{~nL} / \mathrm{min}$, Eksigent Nanolc$2 \mathrm{D})$ with an increasing concentration of Buffer B (acetonitrile/water/formic acid, 98.9/1/0.1; min/\%B: 0/5, 10/10, $112 / 40,130 / 60,135 / 90,140 / 90)$. Eluted peptides were analyzed by MS and data-dependent MS/MS (collision-induced dissociation) using online data-dependent tandem mass spectrometry (LTQ Orbitrap, Thermo Fisher Scientific) in which the seven most abundant precursor ions were selected for MS/MS. Before testing the experimental specimens, the reproducibility of LC-MS/MS analysis was confirmed by examining the triplicates of two different tissue samples, and similar proteins were identified from the triplicates of each sample with more than $90 \%$ overlapping.

2.5. Database Searching and Analysis. BioWorks software (version 3.3.1, Thermo Fisher Sceintific), based on the SEQUEST algorithm (SRF v.5, Thermo Fisher Scientific), was used to search the mass spectra against a human trypsin indexed database (human.fasta.hdr database, Version 12.2, 227246 entries) as described by Whelan et al. [19]. SEQUEST was searched with a fragment ion mass tolerance of $1.00 \mathrm{Da}$ and a parent ion tolerance of $50 \mathrm{PPM}$. The search tolerated up to two missed trypsin cleavages with variable modifications for carboxyamidomethylation (57.02146 Da) and methionine oxidation (15.99492 Da). Scaffold (version 3.0.3, Proteome Software, Inc.) was used to validate MS/MSbased peptide and protein identifications. Peptide identifications were accepted if they could be established at greater than $95.0 \%$ probability as specified by the Peptide Prophet Algorithm [20]. Protein identifications were accepted if they could be established with a greater than $99.0 \%$ probability and contained at least 2 identified peptides. Protein probabilities were assigned by the Protein Prophet Algorithm [21].

From the resulting MS/MS protein identifications, a list of proteins was generated for each sample. A list of semiquantitative protein abundances in the different samples was developed using the normalized spectrum counts of the identified tryptic peptides from each protein, as compiled by the Scaffold program. The protein lists and their relative abundances were then compared to find differentially expressed proteins between two groups.

2.6. Statistic Analysis. The data files exported from Scaffold were further processed as Excel files. The top 60\% (180) abundant proteins of the 315 identified proteins were further selected for hierarchical clustering and supervised classification studies. Those proteins with at least a 2 -fold difference in mean spectral counts between any two groups were selected for analysis in the web-based Gene Expression Profile Analysis Suite (GEPAS, version 4.0, http://www.gepas.org). Five different classification algorithms were tested to select candidate markers in the GEPAS software: Support Vector Machines (SVM), K-Nearest Neighbor Clustering (KNN), Diagonal Linear Discriminant Analysis (DLDA), Prediction
Analysis with Microarrays (PAM), and Self-Organizing Map (SOM).

2.7. Immunohistochemistry Staining. A small portion of each of the baseline tumors was embedded in OCT and stored at $-80^{\circ} \mathrm{C}$. Endogenous peroxidase activity was quenched with $0.6 \%$ hydrogen peroxide in methanol for $10 \mathrm{~min}$ utes, and endogenous biotin was eliminated by Biotin Blocking System (DAKO, x0590). After blocking with 1:5 diluted normal goat serum or fetal bovine serum, slides were incubated for 1 hour with primary antibody (CK19, mouse IgG, ready to use, DAKO; galectin-3-binding protein, Goat $\operatorname{IgG}, 1: 200$ dilution, R\&D) and 30 minutes with biotinylated secondary antibody (biotinylated antimouse Ig, 1:800 dilution, DAKO; biotinylated anti-goat Ig, $1: 200$ dilution, Vector Labs). Antigen-antibody complexes were then detected by the StreptABComplex/HRP method (DAKO) using diaminobenzidine as a chromogenic substrate (DAKO). Immunostained slides were lightly counterstained with hematoxylin. For negative controls, primary antibodies were replaced by mouse IgG or goat IgG.

\section{Results}

3.1. Patient Characteristics. The reported thirty-nine baseline tumor specimens included 28 HER2-positive breast cancers and 11 TNBC with HER2 status determined by fluorescence in situ hybridization (FISH) assay. Fifteen of the 28 HER2+ patients were randomized to receive TC, and the remaining 13 received TC and Herceptin $(\mathrm{TCH})$ before surgery. All eleven patients with TNBC received neoadjuvant TC. Following the neoadjuvant treatment, 28 patients with HER2+ tumors showed 12 responders (R), including 7 with pathological complete response (pCR) and 5 with a tumor regression rate $>75 \%, 12$ intermediate responders (IR), and 4 nonresponders (NR). In the TNBC group, there were 7 responders including $6 \mathrm{pCR}$ and 1 with tumor regression rate $>75 \%, 3$ IR, and $1 \mathrm{NR}$. The clinical characteristics and pathologic features of the 11 TNBC and 28 HER2+ cases are summarized in Tables 1(a) and 1(b).

3.2. Protein Comparison between HER2+ and TNBC Groups. Proteins identified by MS/MS from the 39 tumors showed that 48 proteins were only found in HER2+ tumors, 24 were only seen in TNBC, and 243 proteins were shared by both, but the quantity of the shared proteins differed widely in the two tumor types. In this study, we focused the analysis on the top $60 \%$ abundant proteins $(180 / 315)$ detected in the 39 tumors.

The 20 most abundant shared proteins by both subtypes of cancer were summarized in Table 2. Among them apolipoprotein A-I and D, enolase 1, tumor rejection antigen (gp96) 1, transgelin 2, cofilin 1, profilin, heat shock proteins 70 , and annexins 5 were found to be present in significant quantity in both types of breast cancer. Some of these shared proteins found in sufficient amount may be useful for breast cancer detection. 
TABle 1

(a) Clinical characteristics of 11 TNBC tumors

\begin{tabular}{|c|c|c|c|c|c|c|c|c|c|c|}
\hline LTQ Orbitrap sample ID & Patient age & Ethnicity & TR \% & Response & T stage & Histological type & ER & PR & FISH R/G ratio & Neoadjuvant \\
\hline$\# 1$ & 61 & White & 80 & $\mathrm{R}$ & $\mathrm{T} 3$ & IDC & - & - & 1.10 & TC \\
\hline$\# 2$ & 29 & Hispanic & -60 & NR & T3 & IDC & - & - & 0.92 & TC \\
\hline$\# 5$ & 55 & Hispanic & 100 & $\mathrm{R}(\mathrm{pCR})$ & T3 & IDC & - & - & 0.92 & TC \\
\hline$\# 6$ & 54 & Hispanic & 100 & $\mathrm{R}(\mathrm{pCR})$ & T3 & IDC & - & - & 1.01 & TC \\
\hline$\# 7$ & 40 & Asian & 45 & IR & T3 & IDC & - & - & 1.17 & TC \\
\hline \#8 & 44 & White & $100^{\mathrm{a}}$ & $\mathrm{R}(\mathrm{pCR})$ & T3 & IDC & - & - & 1.00 & TC \\
\hline$\# 9$ & 49 & Hispanic & 48 & IR & $\mathrm{T} 4$ & IDC & - & - & 1.10 & $\mathrm{TC}$ \\
\hline$\# 10$ & 53 & White & 100 & $\mathrm{R}$ (pCR) & T3 & IDC & - & - & 1.20 & TC \\
\hline$\# 11$ & 84 & Asian & 100 & $\mathrm{R}(\mathrm{pCR})$ & $\mathrm{T} 4$ & IDC & - & - & 1.03 & $\mathrm{TC}$ \\
\hline$\# 36$ & 45 & Hispanic & 30 & IR & T3 & IDC & - & - & 1.27 & TC \\
\hline \#37 & 38 & White & 100 & $\mathrm{R}$ (pCR) & $\mathrm{T} 2$ & IDC & - & - & 1.10 & TC \\
\hline
\end{tabular}

${ }^{a} \mathrm{LN}$ positive without residual primary cancer.

(b) Clinical characteristics of 28 HER2+ tumors

\begin{tabular}{|c|c|c|c|c|c|c|c|c|c|c|}
\hline LTQ Orbitrap sample ID & Patient age & Ethnicity & TRR \% & Response & T stage & Histological type & ER & PR & FISH R/G ratio & Neoadjuvant \\
\hline$\# 17$ & 38 & White & 40 & IR & $\mathrm{T} 3$ & IDC & + & - & 12.4 & TC \\
\hline$\# 18$ & 63 & Asian & 100 & $\mathrm{R}(\mathrm{pCR})$ & $\mathrm{T} 3$ & IDC & + & - & 12.7 & $\mathrm{TCH}$ \\
\hline \#19 & 57 & White & 100 & $\mathrm{R}(\mathrm{pCR})$ & T3 & IDC & - & - & 4.6 & TC \\
\hline$\# 20$ & 56 & Asian & 78.2 & $\mathrm{R}$ & $\mathrm{T} 4$ & IDC & + & - & 10.71 & TC \\
\hline$\# 21$ & 51 & Black & 56 & IR & T3 & IDC & - & - & 19.97 & $\mathrm{TCH}$ \\
\hline$\# 22$ & 31 & White & 45.5 & IR & $\mathrm{T} 3$ & IDC & + & + & 2.2 & TC \\
\hline$\# 23$ & 55 & White & 80 & $\mathrm{R}$ & $\mathrm{T} 4$ & IDC & + & + & 3.8 & TC \\
\hline$\# 24$ & 45 & Asian & 75 & IR & $\mathrm{T} 4$ & IDC & + & + & 2.7 & $\mathrm{TCH}$ \\
\hline$\# 25$ & 42 & Hispanic & 63.5 & IR & $\mathrm{T} 4$ & IDC & + & - & 2.5 & TC \\
\hline$\# 26$ & 50 & White & 67.1 & IR & $\mathrm{T} 3$ & IDC & - & - & 2.41 & $\mathrm{TCH}$ \\
\hline$\# 27$ & 33 & White & 82.9 & $\mathrm{R}$ & $\mathrm{T} 3$ & IDC & + & + & 3.03 & $\mathrm{TCH}$ \\
\hline$\# 28$ & 40 & White & 66.7 & IR & $\mathrm{T} 3$ & IDC & - & - & 8.1 & TC \\
\hline$\# 29$ & 35 & Hispanic & $100^{\mathrm{a}}$ & $\mathrm{R}(\mathrm{pCR})$ & T3 & IDC & - & - & 42.2 & $\mathrm{TCH}$ \\
\hline$\# 30$ & 44 & White & 97.3 & $\mathrm{R}$ & $\mathrm{T} 4$ & IDC & - & - & 4.2 & TC \\
\hline$\# 31$ & 30 & White & -7.7 & NR & $\mathrm{T} 3$ & IDC & + & - & 5 & TC \\
\hline$\# 32$ & 57 & White & $25 \%$ & NR & $\mathrm{T} 4$ & IDC & + & - & $>4$ & $\mathrm{TCH}$ \\
\hline$\# 33$ & 37 & White & 33.3 & IR & $\mathrm{T} 2$ & IDC & + & + & 9.49 & TC \\
\hline$\# 34$ & 36 & Black & 25 & NR & $\mathrm{T} 3$ & IDC & - & - & 5.1 & TC \\
\hline$\# 35$ & 42 & White & 60 & IR & $\mathrm{T} 2$ & IDC & + & + & 4.5 & $\mathrm{TCH}$ \\
\hline$\# 38$ & 55 & White & 42.3 & IR & $\mathrm{T} 4$ & IDC & - & - & 3.9 & $\mathrm{TCH}$ \\
\hline$\# 39$ & 47 & White & $100^{\mathrm{b}}$ & $\mathrm{R}$ (pCR) & $\mathrm{T} 3$ & IDC & + & + & $>20$ & $\mathrm{TCH}$ \\
\hline$\# 40$ & 50 & Asian & $100^{\mathrm{b}}$ & $\mathrm{R}$ (pCR) & $\mathrm{T} 3$ & IDC & + & + & 4.19 & $\mathrm{TCH}$ \\
\hline$\# 41$ & 58 & White & 50 & IR & $\mathrm{T} 4$ & IDC & + & + & 2.1 & $\mathrm{TCH}$ \\
\hline$\# 42$ & 40 & Asian & 60 & IR & $\mathrm{T} 2$ & IDC & - & - & 16 & TC \\
\hline$\# 43$ & 37 & White & -85.6 & NR & $\mathrm{T} 3$ & IDC & + & + & 3.1 & TC \\
\hline$\# 44$ & 49 & White & $100^{\mathrm{b}}$ & $\mathrm{R}$ (pCR) & $\mathrm{T} 2$ & IDC & + & - & 7.7 & $\mathrm{TCH}$ \\
\hline$\# 45$ & 55 & Asian & 92.6 & $\mathrm{R}$ & $\mathrm{T} 3$ & IDC & - & - & 9.9 & TC \\
\hline \#46 & 41 & Hispanic & 100 & $\mathrm{R}$ (pCR) & $\mathrm{T} 2$ & IDC & - & - & 9.2 & TC \\
\hline
\end{tabular}

${ }^{a}$ LN positive and residual DCIS; ${ }^{b}$ residual DCIS only. 
TABLE 2: The 20 most abundant proteins shared by both HER2positive and TNBC tumors.

\begin{tabular}{|c|c|c|}
\hline Identified proteins & $\begin{array}{c}\text { Accession } \\
\text { no. }\end{array}$ & MW \\
\hline Apolipoprotein A-I & gi|90108664 & $28 \mathrm{kDa}$ \\
\hline Vimentin & gi|62414289 & $54 \mathrm{kDa}$ \\
\hline Enolase 1 & gi| 4503571 & $47 \mathrm{kDa}$ \\
\hline Alpha-1 antitrypsin & gi| 157086955 & $45 \mathrm{kDa}$ \\
\hline Triosephosphate isomerase 1 & $\begin{array}{c}\mathrm{gi} \mid 4507645 \\
(+2)\end{array}$ & $27 \mathrm{kDa}$ \\
\hline Cyclophilin A & gi| 1633054 & $18 \mathrm{kDa}$ \\
\hline Apolipoprotein D & gi|619383 & $28 \mathrm{kDa}$ \\
\hline Cofilin 1 & gi| 5031635 & $19 \mathrm{kDa}$ \\
\hline Chaperonin & gi|31542947 & $61 \mathrm{kDa}$ \\
\hline Transgelin 2 & gi| 4507357 & $22 \mathrm{kDa}$ \\
\hline Heat shock $70 \mathrm{kDa}$ protein 5 & gi|16507237 & $72 \mathrm{kDa}$ \\
\hline Tumor rejection antigen (gp96) 1 & gi| 4507677 & $92 \mathrm{kDa}$ \\
\hline S100 calcium-binding protein A11 & gi| 5032057 & $12 \mathrm{kDa}$ \\
\hline Lumican precursor & gi $\mid 4505047$ & $38 \mathrm{kDa}$ \\
\hline Tropomyosin 4 & gi| 4507651 & $29 \mathrm{kDa}$ \\
\hline $\begin{array}{l}\text { ATP synthase, } \mathrm{H}+\text { transporting, } \\
\text { mitochondrial F1 complex }\end{array}$ & gi|32189394 & $57 \mathrm{kDa}$ \\
\hline Prosaposin isoform a preproprotein & gi|11386147 & $58 \mathrm{kDa}$ \\
\hline Profilin & $\begin{array}{c}\text { gi } \mid 157838211 \\
(+4)\end{array}$ & $15 \mathrm{kDa}$ \\
\hline Heat shock $70 \mathrm{kDa}$ protein 8 isoform 1 & gi|5729877 & $71 \mathrm{kDa}$ \\
\hline Annexin 5 & gi $\mid 4502107$ & $36 \mathrm{kDa}$ \\
\hline
\end{tabular}

Of the 180 top abundant proteins observed in the 39 breast cancer specimens, 61 were found to have a $\geq 2$-fold difference of spectrum counts between the two subtypes of breast cancer (HER2+ versus TNBC). Because some of these proteins were not detected in every sample, we further refined the list of differential proteins by selecting only those detected in $\geq 50 \%$ of the cases in either group. The selected 44 differentially expressed proteins were tested by hierarchical clustering to classify HER2+ breast cancer versus TNBC. These differentially expressed proteins correctly classified all 28 HER2+ tumors and 8 of the 11 TNBC by unweighted pair-group method using arithmetic average (UPGMA) (Figure 1).

Self-validation of selected proteins in tumor classification was tested using a supervised classification. The 44 differentially expressed proteins were used to build a model separating subtypes of the tumors by Prophet, a web interface from the Gene Expression Profile Analysis Suite. Error rates were calculated as the number of misclassified tumors divided by total tumor cases tested. The error rates using various numbers of proteins by different models (SVM, KNN, DLDA, PAM, and SOM) were estimated by leavingone-out tests (see File A in Supplementary Material available online at doi:10.1155/2011/896476). SVM had the lowest error rate $(10 \%, 4 / 39)$ with $90 \%$ accuracy in tumor classification. The top 20 protein candidates (Table 3 ) selected by SVM model successfully classified all 28 HER2+ tumors and
7 of the 11 TNBC. Among the 20 differentially expressed proteins, G3BP, ALDH1A1, and complement component 1 inhibitor overexpression were found to be associated with TNBC subtype, whereas overexpression of CK19, transferrin, transketolase, and thymosin $\beta 4$ and $\beta 10$ were associated with HER2+ tumors (Figure 2).

3.3. Proteins Correlated with Different Tumor Response to Neoadjuvant Treatment among HER2+ Tumors. Of the 28 HER2+ tumors, there were $12 \mathrm{R}$ (including 7 with pCR), 12 IR, and 4 NR. We compared proteomic differences between the two groups with extreme tumor response (pCR and NR) and found that 48 of the 180 proteins had an expressional difference $\geq 2$-fold between 7 pCR versus 4 NR tumors. Selfvalidation of these potential marker proteins by five supervised classification methods suggested that the KNN had the lowest error rate $(9 \%, 1 / 11)$ in predicting tumor response (Files B and C). By using KNN = 1 method, 100\% (4/4) NR and $85.7 \%(6 / 7)$ pCR were correctly grouped by 20 selected proteins (Table 4). Of the 20 proteins, overexpressions of enolase1, vimentin, and L-plastin in HER2-positive tumors were associated with $\mathrm{pCR}$, whereas high level of heat shock proteins $70(\mathrm{Hsp} 70)$ and peroxiredoxin $5(\operatorname{Prx~V)}$ were found only in the NR cases.

3.4. Proteins Predicting TNBC Tumor Response to Neoadjuvant Treatment. Among the 11 TNBC cases, there were $7 \mathrm{R}$ (including $6 \mathrm{pCR}$ ), $3 \mathrm{IR}$, and $1 \mathrm{NR}$. Due to the small sample size, the proteins of responders' tumor $(R)$ were compared to all the remaining tumors with less response (IR + NR). Sixty-three of 180 proteins had a $\geq 2$-fold mean differences between the two groups of TNBC with different response to the same treatment. Self-validation of these proteins by five supervised classification methods was used to compare the accuracy in predicting a tumor response. Using DLDA method, 6 of 7 tumors in the R group and 3 of 4 tumors in IR/NR group were correctly classified by the 30 selected proteins (error rate 18\%) (Files D and E). Of these 30 proteins, the increased heat shock $70 \mathrm{kDa}$ protein 8 , periostin, Ras homolog gene family member A (RhoA), actinin alpha 4 , cathepsin $\mathrm{D}$ preproprotein, annexin 1 , and several other proteins were associated with drug resistance in TNBC (Table 5).

3.5. Evaluation of CK19 and G3BP Expression in TNBC and HER2+ Frozen Tumors. CK19 and G3BP protein expressions were tested in breast cancer tumors by immunohistochemistry. The CK19 and G3BP staining showed cytoplasmic/membrane staining pattern in breast cancer cells. The overexpression of CK19 was found in HER2+ breast tumors (Figure 3) while the expression of G3BP was found to be upregulated in most TNBC (Figure 4). The concordance findings between the mass spectrometry analysis and immunohistochemical staining of the same tumor suggested that high-throughput mass spectrometry may be used as a screening tool to discover disease-related biomarkers. 
TABLE 3: Top 20 differentially expressed proteins selected by supervised classification methods for classifying two tumor subtypes.

\begin{tabular}{|c|c|c|c|c|c|c|}
\hline Rank & Accession no. & Protein name & MW & $\begin{array}{l}\text { HER } 2+/ \text { TNBC } \\
\text { mean }\end{array}$ & $\begin{array}{l}\text { Subcellular } \\
\text { location }\end{array}$ & Function \\
\hline 1 & gi| 10946578 & Thymosin $\beta 4$ & $5 \mathrm{kDa}$ & 2.99 & $\begin{array}{l}\text { Cytoplasm, } \\
\text { cytoskeleton }\end{array}$ & $\begin{array}{l}\text { For cytoskeletal binding, involved in cell } \\
\text { growth and maintenance }\end{array}$ \\
\hline 2 & gi $\mid 4507521$ & Transketolase & $68 \mathrm{kDa}$ & 4.20 & Cytosol & $\begin{array}{l}\text { Involved in metabolism. Associated with cell } \\
\text { proliferation of uterine and cervical cancer. }\end{array}$ \\
\hline 3 & gi| 1633054 & Cyclophilin A & $18 \mathrm{kDa}$ & 2.45 & Cytoplasma & Involved in accelerate the folding of proteins \\
\hline 4 & gi|73858568 & $\begin{array}{l}\text { Complement } \\
\text { component } 1 \text { inhibitor }\end{array}$ & $55 \mathrm{kDa}$ & 0.33 & Secreted & Regulating the complement cascade \\
\hline 5 & gi $\mid 4557871$ & Transferrin & $77 \mathrm{kDa}$ & 16.38 & Secreted & $\begin{array}{l}\text { Essential for cell growth and iron-dependent } \\
\text { metabolic processes }\end{array}$ \\
\hline 6 & gi|90111766 & $\begin{array}{l}\text { Keratin type I } \\
\text { cytoskeletal } 19\end{array}$ & $44 \mathrm{kDa}$ & 11.29 & Cytoskeleton & $\begin{array}{l}\text { Involved in metastatic progression of breast } \\
\text { cancer }\end{array}$ \\
\hline 7 & gi| 10863895 & Thymosin $\beta 10$ & $5 \mathrm{kDa}$ & 2.25 & $\begin{array}{l}\text { Cytoplasm, } \\
\text { cytoskeleton }\end{array}$ & $\begin{array}{l}\text { For cytoskeletal binding, involved in cell } \\
\text { growth and maintenance }\end{array}$ \\
\hline 8 & gi| 5031863 & $\begin{array}{l}\text { Galectin-3-binding } \\
\text { protein }\end{array}$ & $65 \mathrm{kDa}$ & 0.41 & Secreted & $\begin{array}{l}\text { Modulating cell-cell and cell-matrix } \\
\text { interactions }\end{array}$ \\
\hline 9 & $\begin{array}{l}\text { gi } \mid 4505753 \\
\quad(+1)\end{array}$ & $\begin{array}{l}\text { Phosphoglycerate } \\
\text { mutase } 1\end{array}$ & $29 \mathrm{kDa}$ & 2.51 & Cytosol & Involved in glycolysis \\
\hline 10 & gi|5174391 & $\begin{array}{l}\text { Aldo-keto reductase } \\
\text { family } 1 \text {, member A1 }\end{array}$ & $37 \mathrm{kDa}$ & 0.30 & Cytosol & $\begin{array}{l}\text { Involved in the reduction of biogenic and } \\
\text { xenobiotic aldehydes }\end{array}$ \\
\hline 11 & gi|21361176 & $\begin{array}{l}\text { Aldehyde dehydrogenase } \\
1 \mathrm{~A} 1\end{array}$ & $55 \mathrm{kDa}$ & 0.39 & Cytoplasm & $\begin{array}{l}\text { Detoxifying enzyme responsible for } \\
\text { oxidating of intracellular aldehydes. A } \\
\text { marker for cancer stem cells }\end{array}$ \\
\hline 12 & gi $\mid 4505185$ & $\begin{array}{l}\text { Macrophage migration } \\
\text { inhibitory factor }\end{array}$ & $12 \mathrm{kDa}$ & 0.36 & $\begin{array}{l}\text { Secreted, } \\
\text { cytoplasm }\end{array}$ & Involved in integrin signaling pathways \\
\hline 13 & $\begin{array}{l}\text { gi } \mid 4507645 \\
\quad(+2)\end{array}$ & $\begin{array}{l}\text { Triosephosphate } \\
\text { isomerase } 1\end{array}$ & $27 \mathrm{kDa}$ & 2.49 & $\begin{array}{l}\text { Cytosol, } \\
\text { nucleus }\end{array}$ & $\begin{array}{l}\text { Fatty acid biosynthesis, gluconeogenesis, } \\
\text { glycolysis, lipid synthesis }\end{array}$ \\
\hline 14 & gi $\mid 4930167$ & Aldolase A & $39 \mathrm{kDa}$ & 6.41 & $\begin{array}{l}\text { Extracellular, } \\
\text { cytoskeleton }\end{array}$ & Involved in glycolysis \\
\hline 15 & gi| 116241280 & $\begin{array}{l}\text { Adenylyl } \\
\text { cyclase-associated } \\
\text { protein } 1 \text { (CAP 1) }\end{array}$ & $52 \mathrm{kDa}$ & 3.03 & Membrane & $\begin{array}{l}\text { Regulating filament dynamics, cell polarity } \\
\text { and signal transduction, }\end{array}$ \\
\hline 16 & $\begin{array}{l}\text { gi } \mid 21624607 \\
(+5)\end{array}$ & Coactosin-like 1 & $16 \mathrm{kDa}$ & 0.42 & $\begin{array}{l}\text { Cytoplasm, } \\
\text { cytoskeleton }\end{array}$ & Regulating the actin cytoskeleton \\
\hline 17 & gi| 160420317 & $\begin{array}{l}\text { Filamin A, alpha } \\
\text { isoform } 2\end{array}$ & $281 \mathrm{kDa}$ & 3.10 & Cytoplasm & $\begin{array}{l}\text { Anchoring transmembrane proteins to the } \\
\text { actin cytoskeleton, scaffold for cytoplasmic } \\
\text { signaling proteins }\end{array}$ \\
\hline 18 & gi|6005942 & $\begin{array}{l}\text { Valosin-containing } \\
\text { protein }\end{array}$ & $89 \mathrm{kDa}$ & 3.26 & $\begin{array}{l}\text { Cytosol, } \\
\text { nucleus }\end{array}$ & $\begin{array}{l}\text { Fragmentation of Golgi stacks during } \\
\text { mitosis and reassembly }\end{array}$ \\
\hline 19 & gi|5174539 & $\begin{array}{l}\text { Cytosolic malate } \\
\text { dehydrogenase }\end{array}$ & $36 \mathrm{kDa}$ & 2.52 & Cytoplasm & $\begin{array}{l}\text { Involved glycolysis, oxidation reduction, } \\
\text { and tricarboxylic acid cycle }\end{array}$ \\
\hline 20 & $\begin{array}{c}\text { gi } \mid 33286418 \\
(+2)\end{array}$ & Pyruvate kinase 3 & $58 \mathrm{kDa}$ & 6 & $\begin{array}{l}\text { Cytoplasm, } \\
\text { nucleus }\end{array}$ & Involved in glycolysis \\
\hline
\end{tabular}

\section{Discussion}

In this discovery study, the MS-detected proteomic differences between two subtypes of breast cancer (HER2+ versus TNBC tumors) were explored, and proteomic prediction of tumor response to neoadjuvant chemotherapy was investigated. LC-MS/MS data sets of proteins from the 39 tumors analyzed allowed us to identify several candidate proteins that could classify tumor subtypes and predict tumor response to neoadjuvant chemotherapy.
Two clinical subtypes of breast cancer, HER2-positive and triple-negative breast cancers, defined by immunohistochemical staining and fluorescence in situ hybridization of three biomarkers of breast cancer have also been confirmed by gene analysis as two distinctive types of breast cancer. In this study, we reported that proteomic analysis could also separate the two subtypes by the unique biosignature associated with each type of breast cancer (Table 3 ). We also reported the potential of proteomic analysis in classifying drugresistant TNBC and HER2+ breast cancer (Tables 4 and 5). 
TABLE 4: Top 20 proteins predicting tumor response to neoadjuvant treatment in HER2-positive tumors.

\begin{tabular}{|c|c|c|c|c|c|}
\hline Rank & Protein name & Accession no. & $\begin{array}{c}\mathrm{pCR} / \mathrm{NR} \\
\text { mean }\end{array}$ & $\begin{array}{l}\text { Subcellular } \\
\text { location }\end{array}$ & Function \\
\hline 1 & Enolase 1 & gi $\mid 4503571$ & 2.59 & $\begin{array}{l}\text { Cytoplasm, cell } \\
\text { membrane }\end{array}$ & Multifunctional enzyme \\
\hline 2 & $\begin{array}{l}\text { Heterogeneous nuclear } \\
\text { ribonucleoprotein } \\
\mathrm{A} 2 / \mathrm{B} 1 \text { isoform } \mathrm{B} 1\end{array}$ & gi| 14043072 & 3.51 & $\begin{array}{l}\text { Nucleus, } \\
\text { cytoplasm }\end{array}$ & Pre-mRNA processing \\
\hline 3 & $\begin{array}{l}\text { Heat shock } 70 \mathrm{kDa} \\
\text { protein } 1\end{array}$ & gi|75061728 & 0.24 & Cytoplasm & Stress response \\
\hline 4 & Vimentin & gi|62414289 & 9.94 & Cytosol & Class III intermediate filaments \\
\hline 5 & $\begin{array}{l}\text { Vesicle amine transport } \\
\text { protein } 1\end{array}$ & gi| 18379349 & 0.50 & $\begin{array}{l}\text { Cytoplasmic } \\
\text { vesicle membrane }\end{array}$ & Neurotransmitter transport \\
\hline 6 & $\begin{array}{l}\text { Coronin, actin-binding } \\
\text { protein, 1A }\end{array}$ & gi|5902134 & 2.00 & Cytoplasm & $\begin{array}{l}\text { Component of the cytoskeleton of highly } \\
\text { motile cells }\end{array}$ \\
\hline 7 & $\begin{array}{l}\text { Fatty acid-binding } \\
\text { protein } 4\end{array}$ & $\begin{array}{l}\text { gi } \mid 4557579 \\
\quad(+1)\end{array}$ & 0.23 & $\begin{array}{l}\text { Cytoplasm, } \\
\text { nucleus }\end{array}$ & Lipid transport protein \\
\hline 8 & Peroxiredoxin 5 & gi|15826629 & 0.37 & $\begin{array}{l}\text { Mitochondrion, } \\
\text { cytoplasm, } \\
\text { peroxisome }\end{array}$ & Antioxidant, oxidoreductase peroxidase \\
\hline 9 & $\begin{array}{l}\text { Heat shock } 70 \mathrm{kDa} \\
\text { protein } 9\end{array}$ & gi $\mid 24234688$ & 0.15 & Mitochondrion & Control of cell proliferation and cellular aging \\
\hline 10 & $\begin{array}{l}\text { Leucine aminopeptidase } \\
3\end{array}$ & gi|41393561 & 2.94 & $\begin{array}{l}\text { Cell membrane, } \\
\text { secreted }\end{array}$ & Cell-cell signaling \\
\hline 11 & Apolipoprotein D & gi|619383 & 2.90 & Secreted & Lipid metabolic process \\
\hline 12 & L-plastin & gi $\mid 4504965$ & 3.14 & $\begin{array}{l}\text { Cytoplasm, cell } \\
\text { membrane }\end{array}$ & $\begin{array}{l}\text { Activation of } \mathrm{T} \text { cells, intracellular protein } \\
\text { transport }\end{array}$ \\
\hline 13 & $\begin{array}{l}\text { Anterior gradient } \\
\text { protein } 2 \text { homolog } \\
\text { precursor }\end{array}$ & gi| 5453541 & 0.11 & $\begin{array}{l}\text { Secreted, } \\
\text { endoplasmic } \\
\text { reticulum }\end{array}$ & Mucus secretion \\
\hline 14 & $\begin{array}{l}\text { Heat shock } 10 \mathrm{kDa} \\
\text { protein } 1\end{array}$ & gi $\mid 4504523$ & 0.37 & Mitochondrion & Stress response \\
\hline 15 & $\begin{array}{l}\text { ATP synthase, H+ } \\
\text { transporting, } \\
\text { mitochondrial F1 } \\
\text { complex }\end{array}$ & gi $\mid 4757810$ & 0.41 & Mitochondrion & $\begin{array}{l}\text { Proton-transporting ATP synthase complex } \\
\text { assembly }\end{array}$ \\
\hline 16 & Glutathione transferase & $\begin{array}{l}\text { gi } \mid 20664358 \\
(+5)\end{array}$ & 3.29 & Cytoplasm & Glutathione metabolic process \\
\hline 17 & Chaperonin & gi|31542947 & 0.33 & Mitochondrion & Stress response \\
\hline 18 & $\begin{array}{l}\text { Complement } \\
\text { component } 3 \text { precursor }\end{array}$ & gi| 115298678 & 3.00 & Secreted & Activation of the complement system \\
\hline 19 & $\begin{array}{l}\text { Heterogeneous nuclear } \\
\text { ribonucleoprotein D } \\
\text { isoform a }\end{array}$ & gi| 14110420 & 2.19 & $\begin{array}{l}\text { Nucleus, } \\
\text { cytoplasm }\end{array}$ & Transcription regulation \\
\hline 20 & Malate dehydrogenase & $\begin{array}{c}\text { gi } \mid 6648067 \\
(+1)\end{array}$ & 0.22 & Cytoplasm & Tricarboxylic acid cycle \\
\hline
\end{tabular}

Through an extensive literature review, some of the identified proteins have reported roles that are relevant to cancer biology and treatment. In TNBC tumors, we observed that the levels of G3BP, ALDH1A1, and complement component 1 inhibitor protein were preferentially elevated. All of them have been reported to have important biological properties in cancer progression. G3BP, also known as $90-\mathrm{kDa}$ Mac-2binding protein, is a member of the beta-galactoside-binding protein family and has a role in modulating cell-cell and cell-matrix interactions. It has been shown that G3BP is overexpressed in a variety of cancer cells such as colon, gastric, and breast cancer, and its overexpression appears to correlate with tumor progression, and metastasis [2226]. Our report is the first to describe G3BP overexpression in human TNBC by both mass spectrometry analysis and immunohistochemical staining method.

One protein correlated with triple-negative breast cancer meriting a discussion is ALDH1A1, a detoxifying enzyme responsible for oxidizing intracellular aldehydes. This process is important in early differentiation of stem cells 
TABLE 5: Top 30 proteins predicting tumor response to neoadjuvant chemotherapy in TNBC tumors.

\begin{tabular}{|c|c|c|c|c|c|}
\hline Rank & Protein name & Accession no. & $\begin{array}{c}\mathrm{R} / \mathrm{IR}+\mathrm{NR} \\
\text { mean }\end{array}$ & Subcellular location & Function \\
\hline 1 & $\begin{array}{l}\text { Heat shock } 70 \mathrm{kDa} \text { protein } \\
8 \text { isoform } 1\end{array}$ & gi| 5729877 & 0.32 & & Stress response \\
\hline 2 & $\begin{array}{l}\text { Periostin precursor }(\mathrm{PN}) \\
\text { (osteoblast-specific factor } \\
2 \text { ) }\end{array}$ & gi|93138709 & 0.31 & Nucleus & Transcription regulation \\
\hline 3 & Cyclophilin A & gi| 1633054 & 0.41 & Secreted & Cell attachment adhesion and spreading \\
\hline 4 & $\begin{array}{l}\text { Tyrosine } 3 / \text { tryptophan } \\
\text { 5-monooxygenase } \\
\text { activation protein }\end{array}$ & $\begin{array}{l}\text { gi } \mid 5803225 \\
\quad(+1)\end{array}$ & 3.71 & Nucleus & Protein binding \\
\hline 5 & Profilin & $\begin{array}{c}\text { gi } \mid 157838211 \\
(+4)\end{array}$ & 0.32 & $\begin{array}{l}\text { Cytoplasm, } \\
\text { cytoskeleton }\end{array}$ & Actin cytoskeleton organization \\
\hline 6 & $\begin{array}{l}\text { Cardiac muscle alpha } \\
\text { actin } 1 \text { proprotein }\end{array}$ & gi $\mid 4885049$ & 0.08 & $\begin{array}{l}\text { Cytoplasm, } \\
\text { cytokeleton }\end{array}$ & actin filament-based movement, apoptosis \\
\hline 7 & Beta actin & gi| 4501885 & 0.22 & $\begin{array}{l}\text { Cytoplasm, } \\
\text { cytokeleton }\end{array}$ & Cell motility \\
\hline 8 & Caldesmon (CDM) & gi|2498204 & 0.42 & $\begin{array}{l}\text { Cytoplasm, } \\
\text { cytokeleton }\end{array}$ & Actin- and myosin-binding protein \\
\hline 9 & Tubulin $\beta 5$ & gi| 7106439 & 0.19 & Cytosol & Major constituent of microtubules \\
\hline 10 & $\begin{array}{l}\text { Tropomyosin } 2 \text { (beta) } \\
\text { isoform } 1\end{array}$ & gi|42476296 & 0.11 & $\begin{array}{l}\text { Cytoplasm, } \\
\text { cytokeleton }\end{array}$ & Binding to actin filaments \\
\hline 11 & Actinin, $\alpha 4$ & gi| 12025678 & 0.11 & Nucleus, cytoplasm & Protein transport \\
\hline 12 & $\begin{array}{l}\text { Ras homolog gene family, } \\
\text { member A (RhoA) }\end{array}$ & $\begin{array}{l}\text { gi } \mid 10835049 \\
(+4)\end{array}$ & 0.33 & $\begin{array}{l}\text { Cytoplasm, cell } \\
\text { membrane }\end{array}$ & Regulating a signal transduction pathway \\
\hline 13 & $\begin{array}{l}\text { Heterogeneous nuclear } \\
\text { ribonucleoprotein } \mathrm{K}\end{array}$ & gi| 13384620 & 0.33 & Cytoplasm, nucleus & Pre-mRNA-binding proteins \\
\hline 14 & Tubulin $\alpha 1$ & gi|6755901 & 0.36 & Cytosol & Major constituent of microtubules \\
\hline 15 & Tropomyosin 4 & gi| 4507651 & 0.35 & $\begin{array}{l}\text { Cytoplasm, } \\
\text { cytokeleton }\end{array}$ & Binds to actin filaments \\
\hline 16 & $\begin{array}{l}\text { Complement component } \\
1 \text { inhibitor precursor }\end{array}$ & gi|73858568 & 4.57 & Secreted & Complement pathway \\
\hline 17 & $\begin{array}{l}\text { ATP synthase, } \mathrm{H}+ \\
\text { transporting, } \\
\text { mitochondrial F1 complex }\end{array}$ & gi $\mid 4757810$ & 0.43 & Mitochondrion & $\begin{array}{l}\text { Proton-transporting ATP synthase complex } \\
\text { assembly }\end{array}$ \\
\hline 18 & Calnexin precursor & gi| 10716563 & 0.42 & $\begin{array}{l}\text { Endoplasmic } \\
\text { reticulum } \\
\text { membrane, cell } \\
\text { membrane }\end{array}$ & Calcium-binding protein \\
\hline 19 & $\begin{array}{l}\text { Eukaryotic translation } \\
\text { elongation factor } 1 \text { alpha } 1\end{array}$ & gi $\mid 4503471$ & 0.29 & Cytoplasm & Protein biosynthesis \\
\hline 20 & Annexin I & gi $\mid 4502101$ & 0.25 & $\begin{array}{l}\text { Nucleus, cytoplasm, } \\
\text { membrane }\end{array}$ & Calcium/phospholipid-binding protein \\
\hline 21 & $\begin{array}{l}\text { Triosephosphate } \\
\text { isomerase } 1\end{array}$ & $\begin{array}{l}\text { gi } \mid 4507645 \\
\quad(+2)\end{array}$ & 0.35 & Cytosol, nucleus & $\begin{array}{l}\text { Fatty acid biosynthesis, gluconeogenesis, } \\
\text { glycolysis, lipid synthesis }\end{array}$ \\
\hline 22 & $\begin{array}{l}\text { Cathepsin D } \\
\text { preproprotein }\end{array}$ & gi| 4503143 & 0.35 & Lysosome & proteolysis \\
\hline 23 & $\begin{array}{l}\text { Alpha glucosidase II alpha } \\
\text { subunit isoform } 2\end{array}$ & gi|38202257 & 0.19 & Cytosol & Glycan metabolism, N-glycan metabolism \\
\hline 24 & $\begin{array}{l}\text { Tyrosine } \\
\text { 3-monooxygenase/ } \\
\text { tryptophan } \\
\text { 5-monooxygenase } \\
\text { activation protein }\end{array}$ & $\begin{array}{l}\text { gi } \mid 4507949 \\
\quad(+1)\end{array}$ & 0.42 & Nucleus & Protein binding \\
\hline 25 & Thymosin $\beta 10$ & gi| 10863895 & 0.42 & $\begin{array}{l}\text { Cytoplasm, } \\
\text { cytokeleton }\end{array}$ & cytoskeleton organization \\
\hline
\end{tabular}


TABle 5: Continued.

\begin{tabular}{|c|c|c|c|c|c|}
\hline Rank & Protein name & Accession no. & $\begin{array}{l}\mathrm{R} / \mathrm{IR}+\mathrm{NR} \\
\text { mean }\end{array}$ & Subcellular location & Function \\
\hline 26 & Aconitase 2 precursor & gi| 4501867 & 0.44 & Mitochondrion & $\begin{array}{l}\text { Carbohydrate metabolism, tricarboxylic } \\
\text { acid cycle }\end{array}$ \\
\hline 27 & $\begin{array}{l}\text { Heterogeneous nuclear } \\
\text { ribonucleoprotein D } \\
\text { isoform a }\end{array}$ & gi|14110420 & 0.48 & Nucleus, cytoplasm & Transcription regulation \\
\hline 28 & $\begin{array}{l}\text { Serine (or cysteine) } \\
\text { proteinase inhibitor }\end{array}$ & gi|32454741 & 0.25 & Secreted & $\begin{array}{l}\text { Inhibits activated protein } \mathrm{C} \text {, plasminogen } \\
\text { activator }\end{array}$ \\
\hline 29 & Lumican precursor & gi $\mid 4505047$ & 0.28 & Secreted & Binds to laminin \\
\hline 30 & Apolipoprotein D & gi|619383 & 2.86 & Secreted & Transport \\
\hline
\end{tabular}

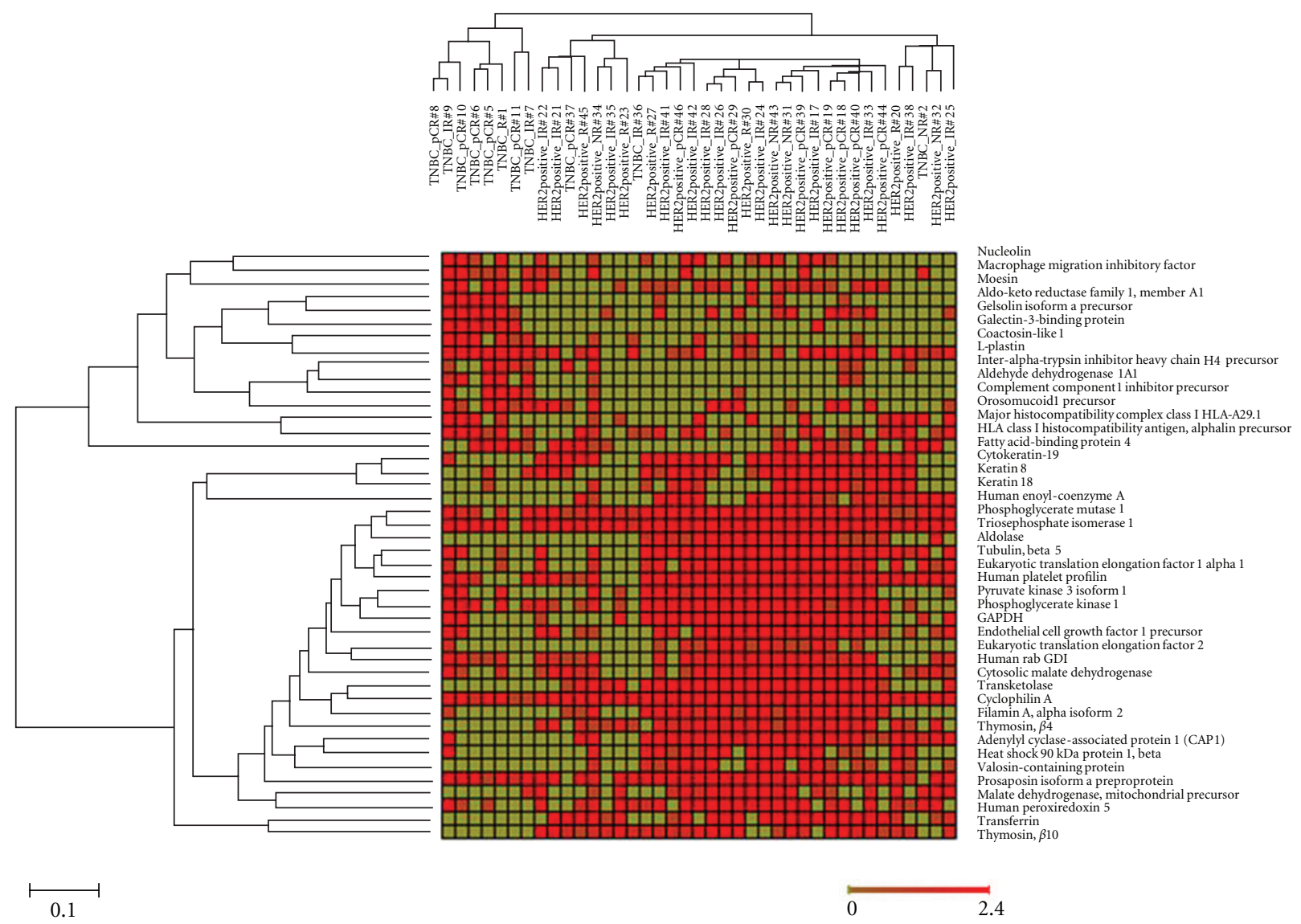

FIGURE 1: Heat map displaying the expression of 44 proteins in 28 HER2-positive and 11 TNBC tumors. Classification of 39 breast cancer cases into 2 groups based on tumor subtypes (HER-positive tumors and TNBC tumors) by the hierarchical clustering using GEPAS software. Each column represents a case as labeled on top, the short labeling cases are "TNBC" with sample ID, and long labeling cases are "HER2positive" with sample ID. Each row represents a protein ID as indicated at the right. 44 proteins were expressed by $\geq 2$-fold differences and detected in $\geq 50 \%$ of the cases in either group.

through conversion of retinol to retinoic acid [27]. ALDH1 is considered to be a breast cancer stem cell marker and also a predictor for poor prognosis [27]. Because breast cancer stem cells have been implicated in radiation and chemotherapy resistance, as well as increasing the potential for metastasis, our finding of ALDH1A1 in TNBC may explain the more frequent relapse in TNBC patients. Previously, we have observed an overexpression of ALDH1 in
TNBC when compared with hormone-receptor-positive and HER2-negative breast cancer [28]. In this paper, we also found a preferential overexpression of ALDH1 in TNBC over HER2-positive tumors. The unique overexpression of ALDH1 in TNBC tumors may point out an important population as the origin of some TNBC whereby notch signaling-dependent stem cell targets may be leveraged for target therapy development [29]. 


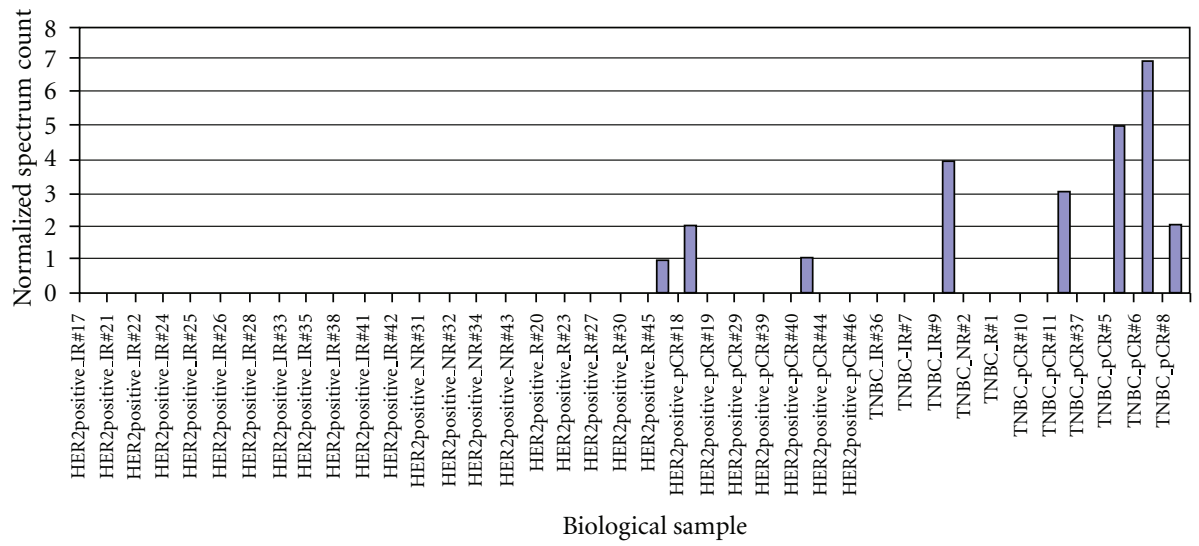

(a) ALDH1Al
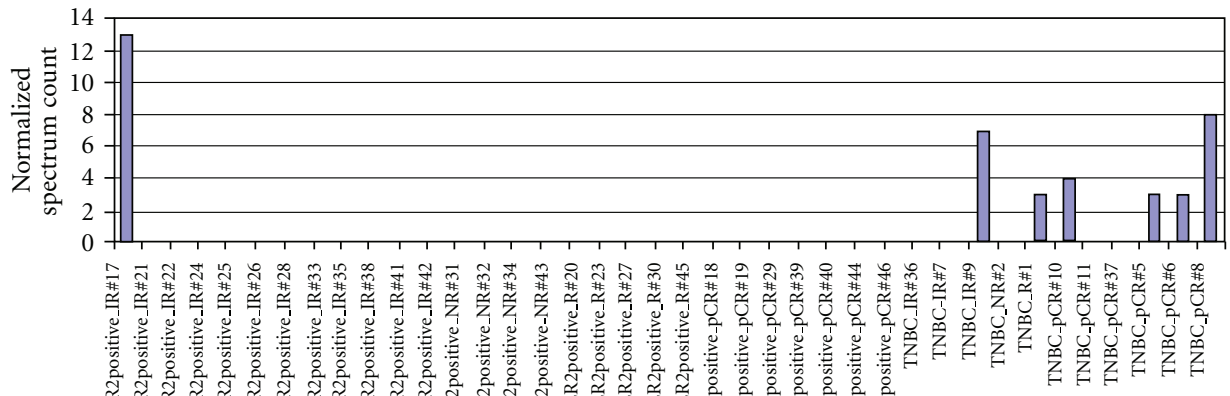

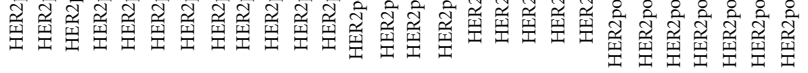

Biological sample

(b) Galectin-3-binding protein
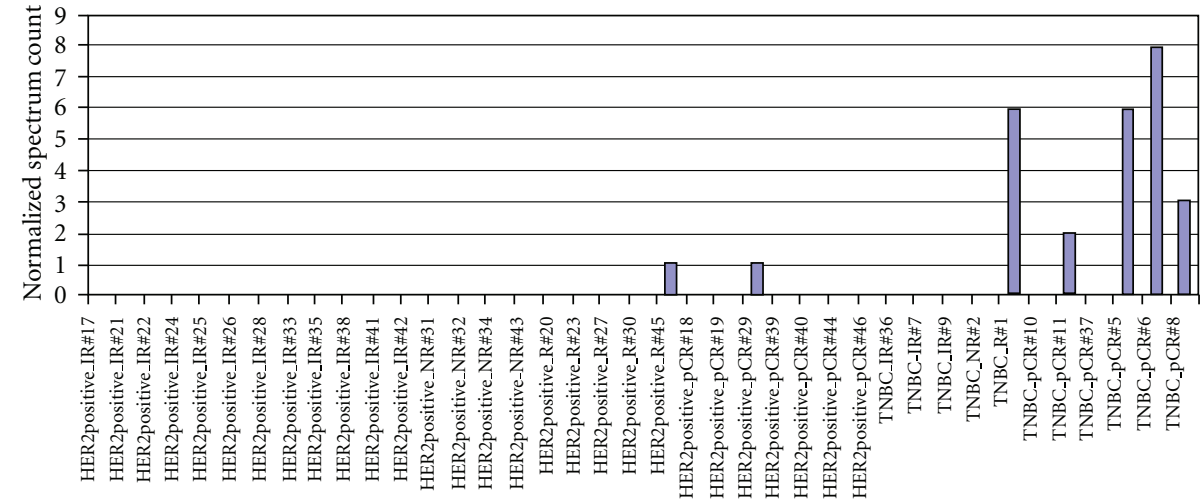

Biological sample

(c) Complement component 1 inhibitor

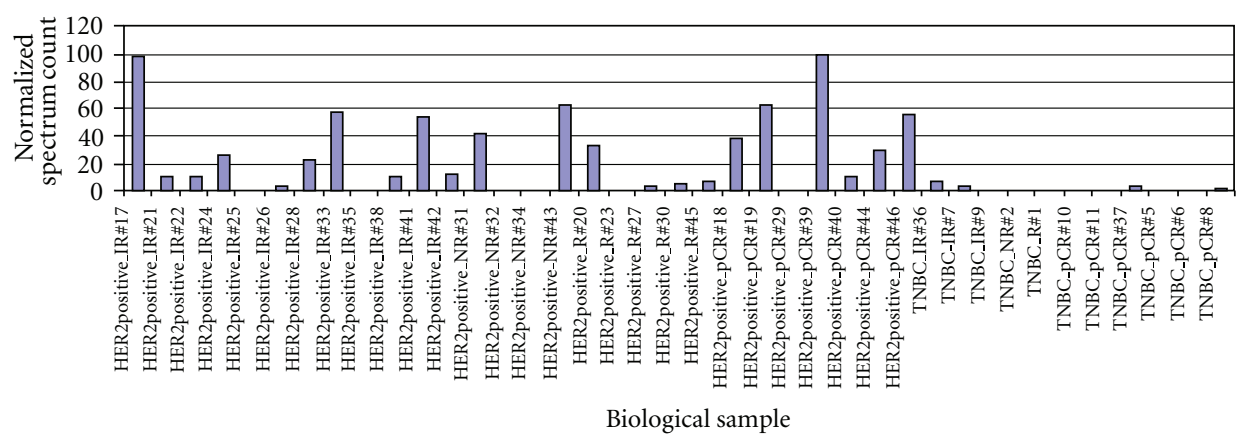

(d) Cytokeratin-19

FIgURe 2: Continued. 


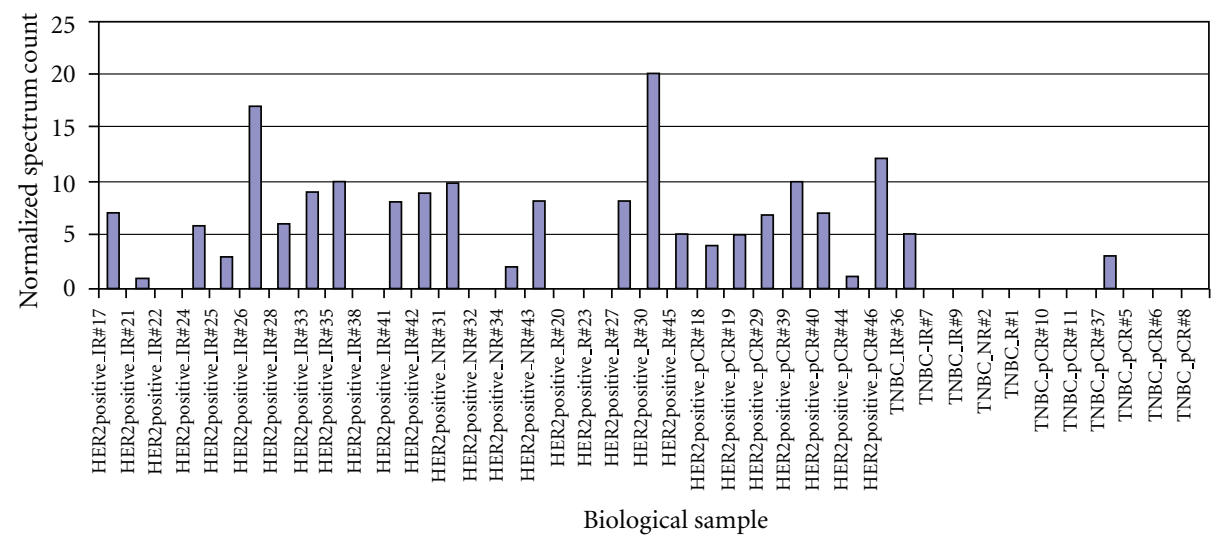

(e) Transketolase

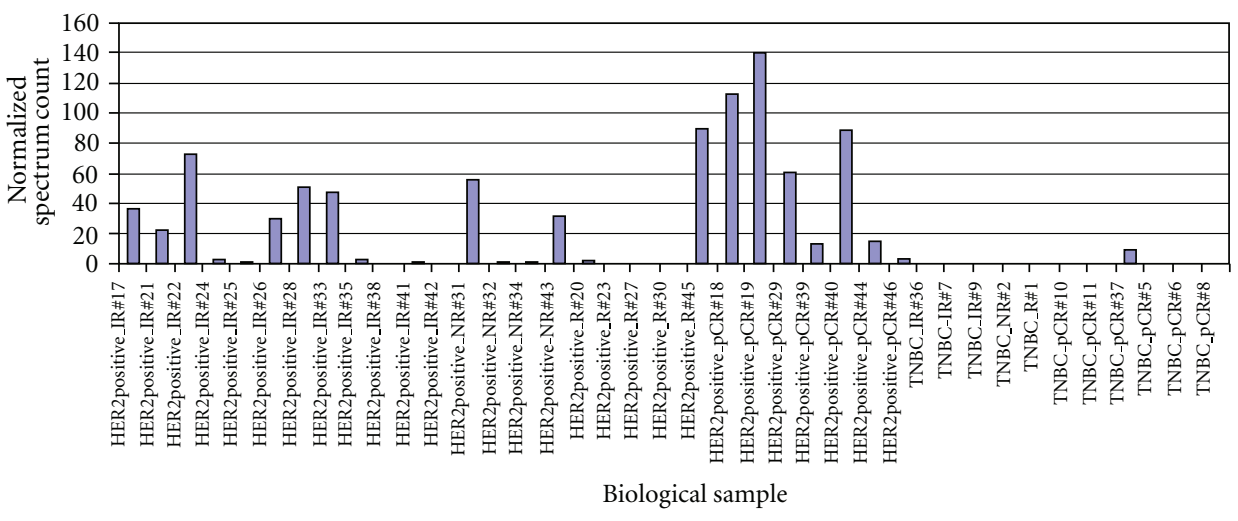

(f) Transferrin

FIGURE 2: Representative proteins differentially expressed by HER2+ and TNBC tumors. (a)-(c): proteins preferentially expressed in TNBC. (d)-(e): proteins preferentially expressed in HER2+ tumors.

A different set of proteins was found preferentially elevated in HER2+ tumors. This list included CK19, transferrin, transketolase, and thymosin $\beta 4$ and $\beta 10$, and the biological significance of some of them will be discussed.

Cytokeratins are known to be important in cellular motility, signaling, and division. While CK8/CK18 were similarly detected in both HER2+ and TNBC tumors, elevated CK19 was more commonly found in HER2+ tumors. Our observation coincides with the finding reported by Schulz et al. using a combination of 2D-DIGE/mass spectrometry and western blot [30]. Both our current and previous papers suggest that CK19 is low in TNBC when compared with either HER2-positive or HER2-negative but hormonereceptor-positive breast cancer [31]. Although the biological significance and the mechanism of reduced CK19 in TNBC are not clear, it could be related to the frequent recurrence and poor overall survival rate seen in TNBC patients [32].

Transferrin, another protein associated with HER2positive cancer, is essential for cell growth and irondependent metabolic activities including DNA synthesis, electron transport, and mitogenic signaling pathways [33]. The elevation of transferrin receptor (CD71) was reported to be a marker of poor outcome [33]. Vyhlidal et al. reported that transferrin is regulated by estrogen hormone
[34], and tamoxifen was shown to be ineffective in ERpositive breast cancer with transferrin overexpression which coincides with the tamoxifen resistance observed in HER2positive hormone-receptor-positive breast cancer. Taken together, the ineffectiveness of tamoxifen in women with HER2-positive and hormone-receptor-positive cancer may be related to the prevalent expression of transferrin in these tumors.

Thymosin $\beta 4$ and $\beta 10$ are members of a family of highly conserved small acid peptides that control the growth and differentiation of many cell types. They act as major actin-sequestering factor and play a role in cancer cell motility, invasion and metastasis [35, 36]. Thymosin $\beta 4$ stimulates tumor metastasis by activating cell migration and angiogenesis in lung cancer and is associated with poor prognosis [37-39]. Elevations of thymosin $\beta 4$ and $\beta 10$ have also been reported in a number of other cancers including melanoma and breast cancer [40]. In the same tumor, the level of thymosin $\beta 10$ was significantly higher in the cancer cells than in the normal breast parenchymal cells of the uninvolved area [41]. Its association with high-grade and poorly differentiated cancer cells is consistent with our findings of thymosin $\beta 10$ overexpression in HER2-positive breast cancer. Further studies are required to confirm its 


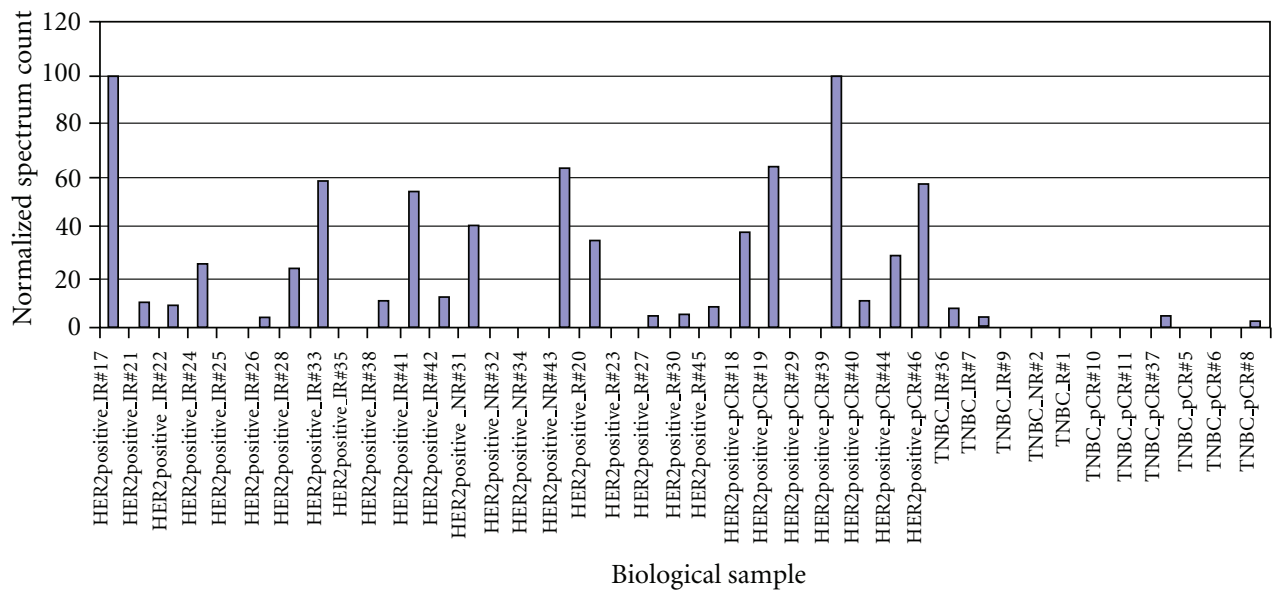

(a) Cytokeratin-19

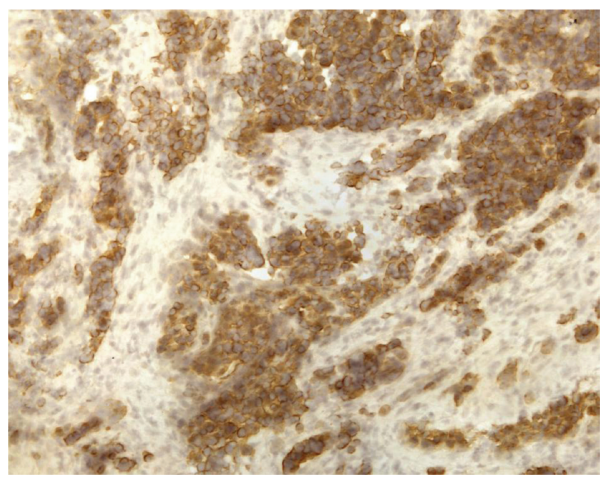

(b)

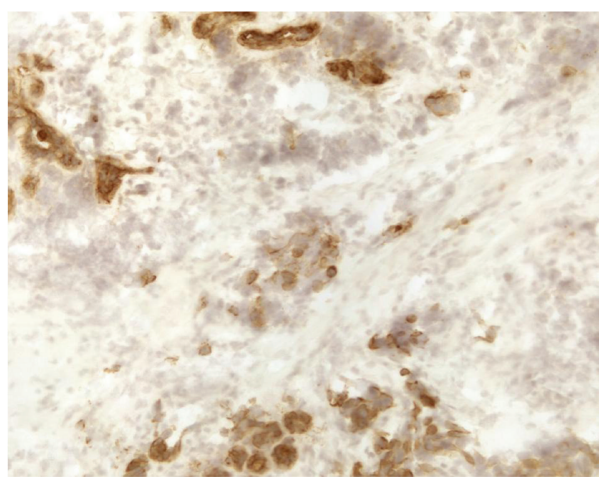

(c)

FIGURE 3: CK19 expressions detected by LC-MS/MS and immunohistochemical (IHC) staining. Elevated CK19 expressions found in HER+ tumor group by LC-MS/MS and confirmed by IHC in most of the frozen HER2+ tumors. (a) Normalized spectrum count of CK19 detected in 39 breast cancer tissues. (b) Immunohistochemical staining of CK19 in a HER2+ frozen tumor (power 200x). (c) Immunohistochemical staining of CK19 in a TNBC frozen tumor (power 200x).

overexpression and to determine its role in HER2-positive breast cancer.

In this study, we also reported the MS-identified protein signature predicting drug-induced tumor response in HER2positive tumors. We found that enolase 1, vimentin, Lplastin, and ApoD predicted a favorable response of HER2positive tumors. In contrast, elevated peroxiredoxin 5 and heat shock proteins 70 were found in nonresponding HER2positive tumors.

Enolase 1(ENO1), a phosphopyruvate dehydratase, is a key glycolytic enzyme involved in anaerobic metabolism under hypoxic conditions of cancer growth, and a cell surface plasminogen receptor for tumor invasion. Overexpression of ENO1 in breast, and lung cancers is associated with tumor progression and rapid tumor growth [42]. While our study did not specifically studying the prognostic value of ENO1, the observation of ENO1 in HER2-positive tumors supports the prognostic importance of this molecule. While it was seen in the more aggressive subtype of breast cancer, our study showed ENO1 elevation in HER2-positive tumors seemed to indicate a better tumor response to chemotherapy.
Vimentin is a member of the intermediate filament family. Along with microtubules and actin microfilaments, vimentin is an integral component of the cell cytoskeleton. In cancer, altered vimentin level is associated with a dedifferentiated phenotype, increased motility, invasiveness, and poor clinical prognosis $[43,44]$. Vimentin overexpression was found in $90.5 \%$ of grade III breast carcinomas [45] which may explain its presence in both HER2-positive breast cancer and in TNBC. Our study found that vimentin, although an aggressive marker for breast cancer growth, is another indicator for a favorable tumor response to chemotherapy. L-plastin is an actin-binding protein involved in cancer cell migration, invasion, and metastasis, and its expression in breast cancer cell lines correlates with the degree of invasiveness $[30,46]$. In this paper, L-plastin overexpression in HER2-positive breast cancer was associated with a likelihood of $\mathrm{pCR}$.

In contrast to those molecules associated with favorable tumor response to neoadjuvant therapy, high levels of $\operatorname{Prx} \mathrm{V}$ in HER2-positive breast cancers were found to be associated with poor response to the same chemotherapy regimen. Peroxiredoxins (Prxs) represent a novel group of peroxidases 


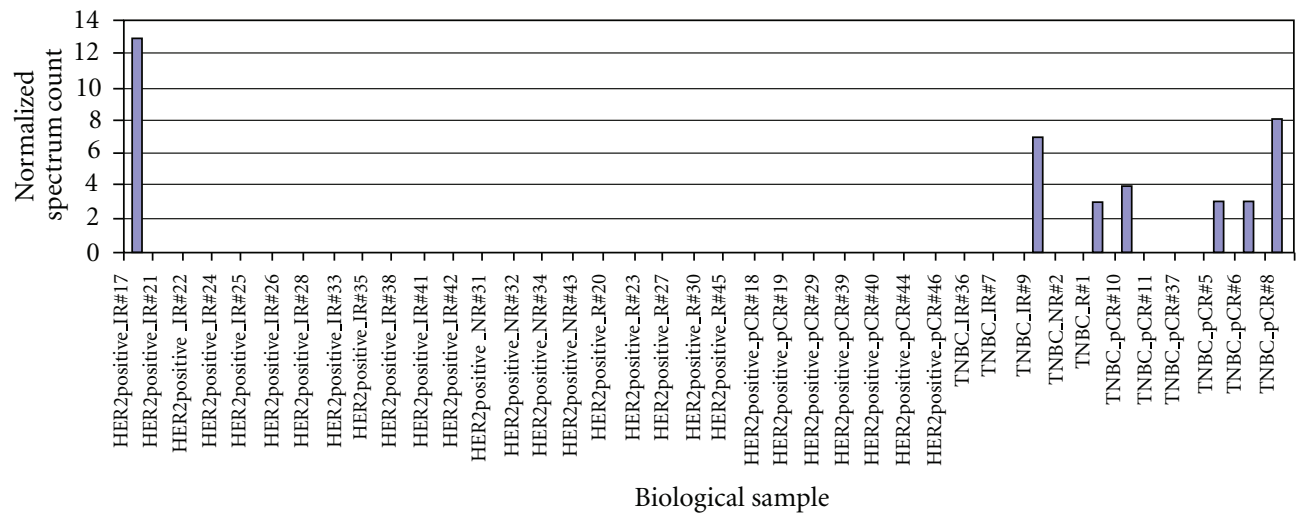

(a) Galectin-3-binding protein

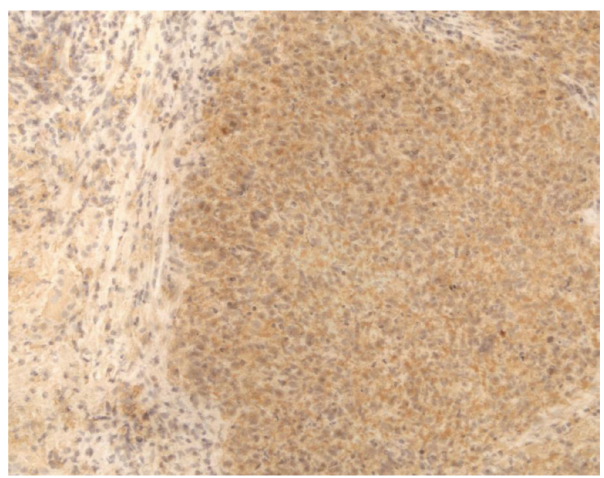

(b)

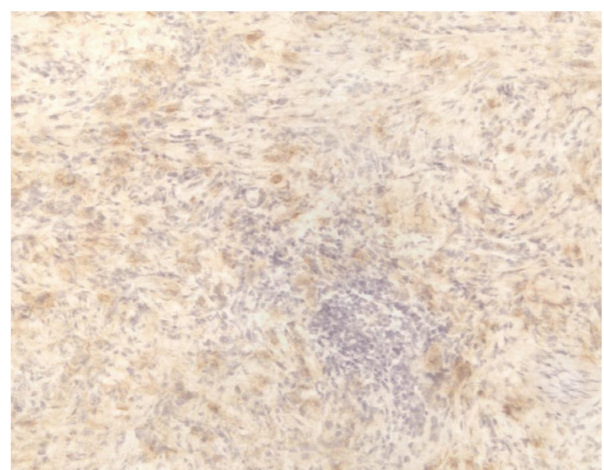

(c)

FIGURE 4: G3BP expressions detected by LC-MS/MS and immunohistochemical (IHC) staining. Elevated G3BP expressions found in TNBC group by LC-MS/MS and confirmed by IHC in most of the frozen TNBC tumors. (a) Normalized spectrum count of G3BP detected from 39 breast cancer tissues. (b) Immunohistochemical staining of G3BP in a TNBC frozen tumor (power 200x). (c) Immunohistochemical staining of G3BP in a HER2+ frozen tumor (power 200x).

containing high antioxidant activity involved in cell differentiation and apoptosis [47], and Prx V is particularly effective in reducing reactive oxygen species (ROS). Moreover, Prx V is found in peroxisomes and mitochondria where protection against ROS is mostly needed. The antioxidant activity of Prx $\mathrm{V}$ may be associated with drug resistance of the tumor cells.

While some molecules are unique to the characteristics of individual subtype of breast cancer, Hsp70 overexpression was found by us to be associated with drug resistance in both HER2-positive and TNBC tumors. Heat shock proteins are overexpressed in a wide range of human cancers and are implicated in tumor cell proliferation, differentiation, death, invasion, metastasis, and immune recognition [48]. Consistent with the cellular functions of Hsp70, clinically it has been correlated with poor prognosis in breast, endometrial, cervical, and bladder cancers. Others have also reported that Hsp70 mediated drug resistance through its inhibitory effect on chemotherapy-induced tumor cell apoptosis [48-50].

In TNBC tumors, a list of different proteins was found to be overexpressed in tumors resistant to neoadjuvant chemotherapy. In addition to Hsp70, proteins such as periostin precursor (OSF-2), RhoA, actinin $\alpha 4$, cathepsin D preproprotein, and annexin 1 predicted a poor response of TNBC to treatment. Although all of them were known to have important cancer biological properties, they have not been linked to chemotherapy susceptibility until now.

Periostin was originally identified in a mouse osteoblastic cell line as an extracellular matrix adhesion protein for preosteoblasts. In addition to forming bones, teeth, and heart, periostin was recently found to be overexpressed in various types of human cancer. Periostin interacts with multiple cell-surface receptors (most notable integrins) and signals via the PI3-K/Akt and other pathways to promote cancer cell survival, epithelial-mesenchymal transition, invasion, and metastasis [51]. In breast cancer, periostin was found upregulated at both the mRNA and protein levels [51-55]. Activation of the Akt/PKB cellular survival pathway with consequential protection of tumor cells and endothelial cells from stress-induced cell death $[51,56]$ may contribute to the periostin-mediated drug resistance in cancer. To our knowledge, this is the first paper to link periostin to drug resistance in TNBC.

RhoA is a member of the Ras superfamily. It is involved in the regulation and timing of cell division. It is a small GTPase protein known to regulate the actin cytoskeleton in the formation of stress fibers. RhoA protein levels were significantly increased in breast cancer compared with the matched normal tissue. It has been reported by Fritz et al. 
that an elevated RhoA protein level correlated with increasing breast tumor grade and poor prognosis [57].

Actinin $\alpha 4$ is another interesting protein that we found to indicate a poor tumor response to neoadjuvant therapy. It is thought that the actinin $\alpha 4$ cross-links actin filaments and connects the actin cytoskeleton to the cell membrane. The accumulation of actinin $\alpha 4$ in the cytoplasm is related to tumor invasiveness and metastasis, probably by enhancing cell motility, and was suggested to be a novel prognosticator in patients with ovarian and breast cancer [58].

Cathepsin D, an acid protease, is active in intracellular protein breakdown and is involved in the pathogenesis of several diseases. Its preproprotein secreted by cancer cells, acting as a mitogen on both cancer and stromal cells, stimulates both proinvasive and prometastatic properties of cancer cells. Many studies found that cathepsin D preproprotein/cathepsin D level represents an independent prognostic factor in a variety of cancers and is, therefore, considered to be a potential target for anticancer therapy [59]. Others have also shown that overexpression of cathepsin D in human breast cancers is associated with a higher risk of relapse and metastasis [59-61]. In our study, cathepsin D preproprotein appeared to be a drug-resistant marker in TNBC.

Although many proteins identified in this pilot study are interesting with promising potential, this study has several limitations. First, the tumors used in this study were collected from a clinical trial which provided many controlled clinical data; however, the sample size available for proteomic analysis was small. As a result, the findings derived from a small sample size always warrant a cautious interpretation. Second, the HER2-positive group consisted of tumors with different ER and PR status which might interfere with the conclusion. The potential false associations with HER2 might be solved by stratifying the HER2positive tumors according to hormonal receptor status in a larger study. Lastly, the HER2-positive patients in this study were randomized to receive either chemotherapy alone or chemotherapy with Herceptin. The selected drugresistant markers may represent the resistance not only to the chemotherapy but also to Herceptin.

In summary, our study has led to the identification of a list of important breast cancer proteins. The study also suggests that MS-based protein profiling may be an important tool in discovery of cancer biosignatures for tumor subtyping and prediction of treatment outcome. When sufficiently validated, some of these candidate protein markers could be used to improve breast cancer care. In addition, due to the heterogeneous and complex nature of the breast cancer tissue specimens, more refined methods need to be developed to maximize the protein identification to allow the capture of the best protein candidate markers for clinical use.

\section{Abbreviations}

DLDA: Diagonal linear discriminant analysis

G3BP: Galectin-3-binding protein

GEPAS: Gene expression pattern analysis suite
IR: $\quad$ Intermediate responders ( $>25 \%$ but $\leq 75 \%$ tumor regression)

KNN: K nearest neighbor

MS: $\quad$ Mass spectrometry

NR: Nonresponders, chemoresistant tumors ( $\leq 25 \%$ tumor regression)

PAM: Prediction analysis with microarrays

pCR: Pathological complete response, no residual cancer found at primary tumor site

R: $\quad$ Responders ( $>75 \%$ of tumor regression)

SOM: Self-organizing map

SVM: Support vector machines

$\mathrm{TC} \pm \mathrm{H}:$ Taxotere/Carboplatin/ \pm Herceptin treatment

TNBC: Triple negative breast tumors

TRR: Tumor regression rate.

\section{Conflict of Interests}

The authors declare that they have no conflict of interests.

\section{Funding}

Grant support: The present study was supported by grant funds from NIH (NCI no. 1RO1 CA 093736-01A1), the Gonda Foundation, the Entertainment Industry Foundation (EIF)/Women's Cancer Research Fund, and the Friends of the Breast Program at UCLA.

\section{Acknowledgments}

The authors thank Jeffrey A. Gornbein (Department of Biomathematics, UCLA) for providing critical advice on statistical analysis.

\section{References}

[1] R. W. Carlson, E. Brown, H. J. Burstein et al., "NCCN task force report: adjuvant therapy for breast cancer," Journal of the National Comprehensive Cancer Network, vol. 4, supplement 1, pp. S1-S26, 2006.

[2] J. Baselga, L. Gianni, C. Geyer, E. A. Perez, A. Riva, and C. Jackisch, "Future options with trastuzumab for primary systemic and adjuvant therapy," Seminars in Oncology, vol. 31, no. 5, supplement 10, pp. 51-57, 2004.

[3] J. S. Ross, D. P. Schenkein, R. Pietrusko et al., "Targeted therapies for cancer 2004," American Journal of Clinical Pathology, vol. 122, no. 4, pp. 598-609, 2004.

[4] P. C. Fong, D. S. Boss, T. A. Yap et al., "Inhibition of poly(ADPribose) polymerase in tumors from BRCA mutation carriers," The New England Journal of Medicine, vol. 361, no. 2, pp. 123134, 2009.

[5] C. K. Anders, E. P. Winer, J. M. Ford et al., "Poly(ADP-ribose) polymerase inhibition: "targeted" therapy for triple-negative breast cancer," Clinical Cancer Research, vol. 16, no. 19, pp. 4702-4710, 2010.

[6] R. Radpour, Z. Barekati, C. Kohler, W. Holzgreve, and X. Y. Zhong, "New trends in molecular biomarker discovery for breast cancer," Genetic Testing and Molecular Biomarkers, vol. 13 , no. 5, pp. 565-571, 2009. 
[7] J. S. Reis-Filho and A. N. J. Tutt, "Triple negative tumours: a critical review," Histopathology, vol. 52, no. 1, pp. 108-118, 2008.

[8] C. M. Perou, T. Sørile, M. B. Eisen et al., "Molecular portraits of human breast tumours," Nature, vol. 406, no. 6797, pp. 747752,2000

[9] T. Sørlie, C. M. Perou, R. Tibshirani et al., "Gene expression patterns of breast carcinomas distinguish tumor subclasses with clinical implications," Proceedings of the National Academy of Sciences of the United States of America, vol. 98, no. 19, pp. 10869-10874, 2001.

[10] T. Sørlie, R. Tibshirani, J. Parker et al., "Repeated observation of breast tumor subtypes in independent gene expression data sets," Proceedings of the National Academy of Sciences of the United States of America, vol. 100, no. 14, pp. 8418-8423, 2003.

[11] H. R. Chang, "Trastuzumab-based neoadjuvant therapy in patients with HER2-positive breast cancer," Cancer, vol. 116, no. 12, pp. 2856-2867, 2010.

[12] V. Kulasingam and E. P. Diamandis, "Strategies for discovering novel cancer biomarkers through utilization of emerging technologies," Nature Clinical Practice Oncology, vol. 5, no. 10, pp. 588-599, 2008.

[13] N. L. Anderson and N. G. Anderson, "The human plasma proteome: history, character, and diagnostic prospects," Molecular \& Cellular Proteomics, vol. 1, no. 11, pp. 845-867, 2002.

[14] H. Hondermarck, C. Tastet, I. E. Yazidi-Belkoura, R. A. Toillon, and X. L. Bourhis, "Proteomics of breast cancer: the quest for markers and therapeutic targets," Journal of Proteome Research, vol. 7, no. 4, pp. 1403-1411, 2008.

[15] C. Röwer, J. P. C. Vissers, C. Koy et al., “Towards a proteome signature for invasive ductal breast carcinoma derived from label-free nanoscale LC-MS protein expression profiling of tumorous and glandular tissue," Analytical and Bioanalytical Chemistry, vol. 395, no. 8, pp. 2443-2456, 2009.

[16] J. He, D. Shen, D. U. Chung et al., "Tumor proteomic profiling predicts the susceptibility of breast cancer to chemotherapy," International Journal of Oncology, vol. 35, no. 4, pp. 683-692, 2009.

[17] H. R. Chang, J. Glaspy, M. A. Allison et al., "Differential response of triple-negative breast cancer to a docetaxel and carboplatin-based neoadjuvant treatment," Cancer, vol. 116, no. 18, pp. 4227-4237, 2010.

[18] N. Rifai, M. A. Gillette, and S. A. Carr, "Protein biomarker discovery and validation: the long and uncertain path to clinical utility," Nature Biotechnology, vol. 24, no. 8, pp. 971983, 2006

[19] S. A. Whelan, M. Lu, J. He et al., "Mass spectrometry (LCMS/MS) site-mapping of N-glycosylated membrane proteins for breast cancer biomarkers," Journal of Proteome Research, vol. 8, no. 8, pp. 4151-4160, 2009.

[20] A. Keller, A. I. Nesvizhskii, E. Kolker, and R. Aebersold, "Empirical statistical model to estimate the accuracy of peptide identifications made by MS/MS and database search," Analytical Chemistry, vol. 74, no. 20, pp. 5383-5392, 2002.

[21] A. I. Nesvizhskii, A. Keller, E. Kolker, and R. Aebersold, "A statistical model for identifying proteins by tandem mass spectrometry," Analytical Chemistry, vol. 75, no. 17, pp. 46464658, 2003.

[22] T. A. Ulmer, V. Keeler, L. Loh et al., "Tumor-associated antigen 90K/Mac-2-binding protein: possible role in colon cancer," Journal of Cellular Biochemistry, vol. 98, no. 5, pp. 1351-1366, 2006.
[23] Y. P. Park, S. C. Choi, J. H. Kim et al., "Up-regulation of Mac2 binding protein by hTERT in gastric cancer," International Journal of Cancer, vol. 120, no. 4, pp. 813-820, 2007.

[24] F. Mbeunkui, B. J. Metge, L. A. Shevde, and L. K. Pannell, "Identification of differentially secreted biomarkers using LCMS/MS in isogenic cell lines representing a progression of breast cancer," Journal of Proteome Research, vol. 6, no. 8, pp. 2993-3002, 2007.

[25] Y. Wang, X. Ao, H. Vuong et al., "Membrane glycoproteins associated with breast tumor cell progression identified by a lectin affinity approach," Journal of Proteome Research, vol. 7, no. 10, pp. 4313-4325, 2008.

[26] Q. Zhao, X. Guo, G. B. Nash et al., "Circulating galectin3 promotes metastasis by modifying MUC1 localization on cancer cell surface," Cancer Research, vol. 69, no. 17, pp. 67996806, 2009.

[27] C. Ginestier, M. H. Hur, E. Charafe-Jauffret et al., "ALDH1 is a marker of normal and malignant human mammary stem cells and a predictor of poor clinical outcome," Cell Stem Cell, vol. 1, no. 5, pp. 555-567, 2007.

[28] M. Lu, J. P. Whitelegge, S. A. Whelan et al., "Hydrophobic fractionation enhances novel protein detection by mass spectrometry in triple negative breast cancer," Journal of Proteomics and Bioinformatics, vol. 3, no. 2, pp. 1-10, 2010.

[29] J. P. Sullivan, M. Spinola, M. Dodge et al., "Aldehyde dehydrogenase activity selects for lung adenocarcinoma stem cells dependent on notch signaling," Cancer Research, vol. 70, no. 23, pp. 9937-9948, 2010.

[30] D. M. Schulz, C. Böllner, G. Thomas et al., "Identification of differentially expressed proteins in triple-negative breast carcinomas using DIGE and mass spectrometry," Journal of Proteome Research, vol. 8, no. 7, pp. 3430-3438, 2009.

[31] M. Lu, S. A. Whelan, J. He et al., "Hydrophobic proteome analysis of triple negative and hormone-receptor- positiveher2-negative breast cancer by mass spectrometer," Clinical Proteomics, vol. 6, no. 3, pp. 93-103, 2010.

[32] R. R. Parikh, Q. Yang, S. A. Higgins, and B. G. Haffty, "Outcomes in young women with breast cancer of triple-negative phenotype: the prognostic significance of CK19 expression," International Journal of Radiation Oncology Biology Physics, vol. 70, no. 1, pp. 35-42, 2008.

[33] H. O. Habashy, D. G. Powe, C. M. Staka et al., "Transferrin receptor (CD71) is a marker of poor prognosis in breast cancer and can predict response to tamoxifen," Breast Cancer Research and Treatment, vol. 119, no. 2, pp. 283-293, 2010.

[34] C. Vyhlidal, X. Li, and S. Safe, "Estrogen regulation of transferrin gene expression in MCF-7 human breast cancer cells," Journal of Molecular Endocrinology, vol. 29, no. 3, pp. 305-317, 2002.

[35] T. Nakagawa, S. K. Huang, S. R. Martinez et al., "Proteomic profiling of primary breast cancer predicts axillary lymph node metastasis," Cancer Research, vol. 66, no. 24, pp. 1182511830, 2006.

[36] A. L. Goldstein, “Thymosin $\beta 4$ : a new molecular target for antitumor strategies," Journal of the National Cancer Institute, vol. 95, no. 22, pp. 1646-1647, 2003.

[37] H. J. Cha, M. J. Jeong, and H. K. Kleinman, "Role of thymosin $\beta 4$ in tumor metastasis and angiogenesis," Journal of the National Cancer Institute, vol. 95, no. 22, pp. 1674-1680, 2003.

[38] S. M. J. Rahman, A. L. Gonzalez, M. Li et al., "Lung cancer diagnosis from proteomic analysis of preinvasive lesions," Cancer Research, vol. 71, no. 8, pp. 3009-3017, 2011. 
[39] B. J. Xu, A. L. Gonzalez, T. Kikuchi et al., "MALDI-MS derived prognostic protein markers for resected non-small cell lung cancer," Proteomics-Clinical Applications, vol. 2, no. 10-11, pp. 1508-1517, 2008.

[40] C. W. Sutton, N. Rustogi, C. Gurkan et al., "Quantitative proteomic profiling of matched normal and tumor breast tissues," Journal of Proteome Research, vol. 9, no. 8, pp. 38913902, 2010.

[41] S. Verghese-Nikolakaki, N. Apostolikas, E. Livaniou, D. S. Ithakissios, and G. P. Evangelatos, "Preliminary findings on the expression of thymosin beta-10 in human breast cancer," British Journal of Cancer, vol. 74, no. 9, pp. 1441-1444, 1996.

[42] A. Hennipman, B. A. van Oirschot, J. Smits, G. Rijksen, and G. E. J. Staal, "Glycolytic enzyme activities in breast cancer metastases,” Tumor Biology, vol. 9, no. 5, pp. 241-248, 1988.

[43] M. I. Kokkinos, R. Wafai, M. K. Wong, D. F. Newgreen, E. W. Thompson, and M. Waltham, "Vimentin and epithelial-mesenchymal transition in human breast cancerobservations in vitro and in vivo," Cells Tissues Organs, vol. 185, no. 1-3, pp. 191-203, 2007.

[44] M. J. C. Hendrix, E. A. Seftor, R. E. B. Seftor, and K. T. Trevor, "Experimental co-expression of vimentin and keratin intermediate filaments in human breast cancer cells results in phenotypic interconversion and increased invasive behavior," American Journal of Pathology, vol. 150, no. 2, pp. 483-495, 1997.

[45] E. Korsching, J. Packeisen, C. Liedtke et al., "The origin of vimentin expression in invasive breast cancer: epithelialmesenchymal transition, myoepithelial histogenesis or histogenesis from progenitor cells with bilinear differentiation potential?" Journal of Pathology, vol. 206, no. 4, pp. 451-457, 2005.

[46] C. S. Lin, Z. P. Chen, T. Park, K. Ghosh, and J. Leavitt, "Characterization of the human L-plastin gene promoter in normal and neoplastic cells," Journal of Biological Chemistry, vol. 268, no. 4, pp. 2793-2801, 1993.

[47] P. Karihtala, A. Mäntyniemi, S. W. Kang, V. L. Kinnula, and Y. Soini, "Peroxiredoxins in breast carcinoma," Clinical Cancer Research, vol. 9, no. 9, pp. 3418-3424, 2003.

[48] D. R. Ciocca and S. K. Calderwood, "Heat shock proteins in cancer: diagnostic, prognostic, predictive, and treatment implications," Cell Stress and Chaperones, vol. 10, no. 2, pp. 86-103, 2005.

[49] M. Jäättelä, "Escaping cell death: survival proteins in cancer," Experimental Cell Research, vol. 248, no. 1, pp. 30-43, 1999.

[50] D. D. Mosser, A. W. Caron, L. Bourget et al., "The chaperone function of hsp70 is required for protection against stressinduced apoptosis," Molecular and Cellular Biology, vol. 20, no. 19, pp. 7146-7159, 2000.

[51] K. Ruan, S. Bao, and G. Ouyang, "The multifaceted role of periostin in tumorigenesis," Cellular and Molecular Life Sciences, vol. 66, no. 14, pp. 2219-2230, 2009.

[52] R. Shao, S. Bao, X. Bai et al., "Acquired expression of periostin by human breast cancers promotes tumor angiogenesis through up-regulation of vascular endothelial growth factor receptor 2 expression," Molecular and Cellular Biology, vol. 24, no. 9, pp. 3992-4003, 2004.

[53] X. Liang, J. Zhao, M. Hajivandi et al., "Quantification of membrane and membrane-bound proteins in normal and malignant breast cancer cells isolated from the same patient with primary breast carcinoma," Journal of Proteome Research, vol. 5, no. 10, pp. 2632-2641, 2006.
[54] X. Liang, J. Huuskonen, M. Hajivandi et al., "Identification and quantification of proteins differentially secreted by a pair of normal and malignant breast-cancer cell lines," Proteomics, vol. 9, no. 1, pp. 182-193, 2009.

[55] Y. Zhang, G. Zhang, J. Li, Q. Tao, and W. Tang, "The expression analysis of periostin in human breast cancer," Journal of Surgical Research, vol. 160, no. 1, pp. 102-106, 2010.

[56] L. Gillan, D. Matei, D. A. Fishman, C. S. Gerbin, B. Y. Karlan, and D. D. Chang, "Periostin secreted by epithelial ovarian carcinoma is a ligand for $\alpha \mathrm{V} \beta 3$ and $\alpha \mathrm{V} \beta 5$ integrins and promotes cell motility," Cancer Research, vol. 62, no. 18, pp. 5358-5364, 2002.

[57] G. Fritz, C. Brachetti, F. Bahlmann, M. Schmidt, and B. Kaina, "Rho GTPases in human breast tumours: expression and mutation analyses and correlation with clinical parameters," British Journal of Cancer, vol. 87, no. 6, pp. 635-644, 2002.

[58] K. Honda, T. Yamada, R. Endo et al., "Actinin-4, a novel actin-bundling protein associated with cell motility and cancer invasion," Journal of Cell Biology, vol. 140, no. 6, pp. 13831393, 1998.

[59] P. Benes, V. Vetvicka, and M. Fusek, "Cathepsin D-many functions of one aspartic protease," Critical Reviews in Oncology/Hematology, vol. 68, no. 1, pp. 12-28, 2008.

[60] S. M. Thorpe, H. Rochefort, M. Garcia et al., "Association between high concentrations of $\mathrm{M}(\mathrm{r}) 52,000$ cathepsin D and poor prognosis in primary human breast cancer," Cancer Research, vol. 49, no. 21, pp. 6008-6014, 1989.

[61] F. Spyratos, T. Maudelonde, J. P. Brouillet et al., "Cathepsin D: an independent prognostic factor for metastasis breast cancer," The Lancet, vol. 2, no. 8672, pp. 1115-1118, 1989. 

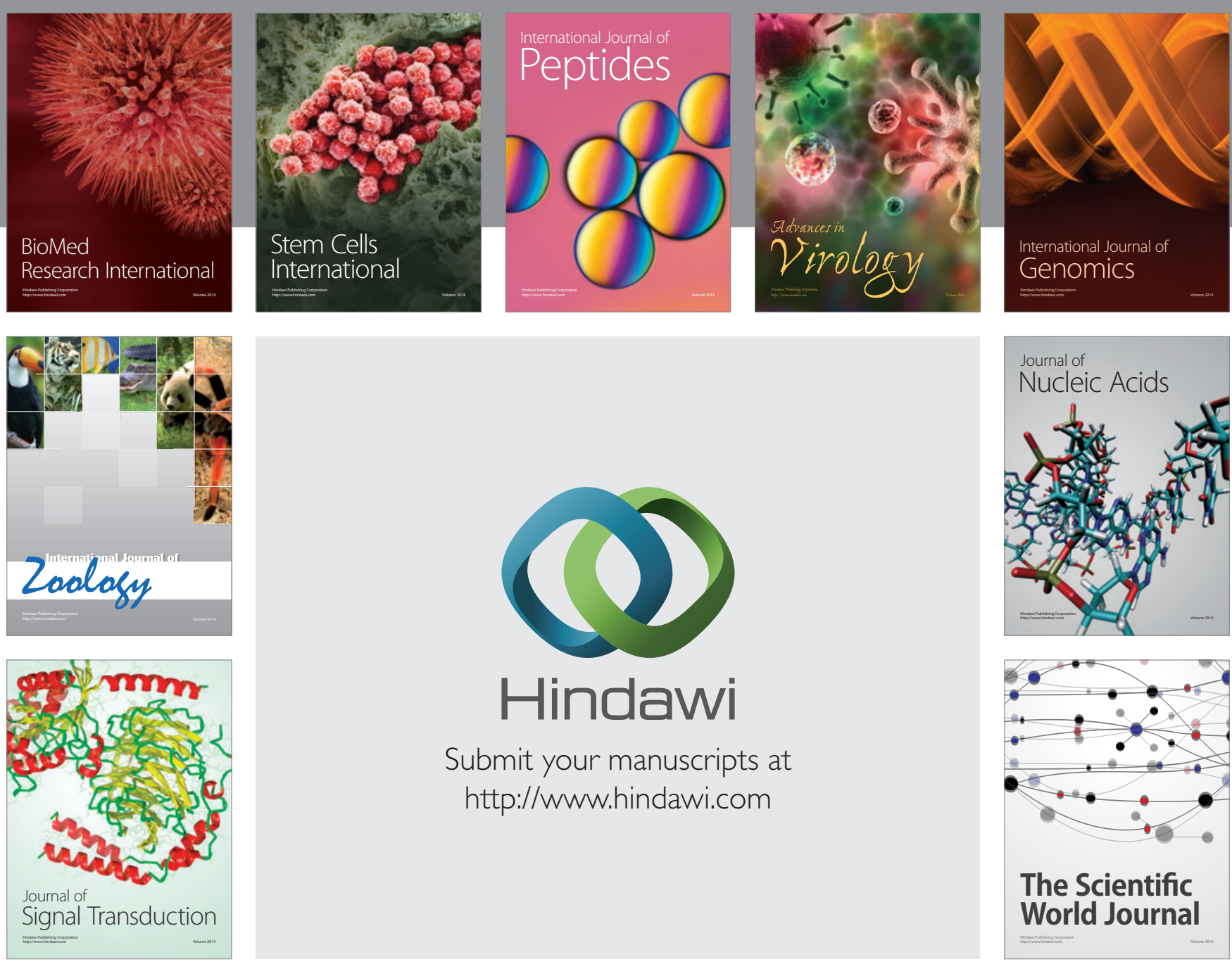

Submit your manuscripts at

http://www.hindawi.com
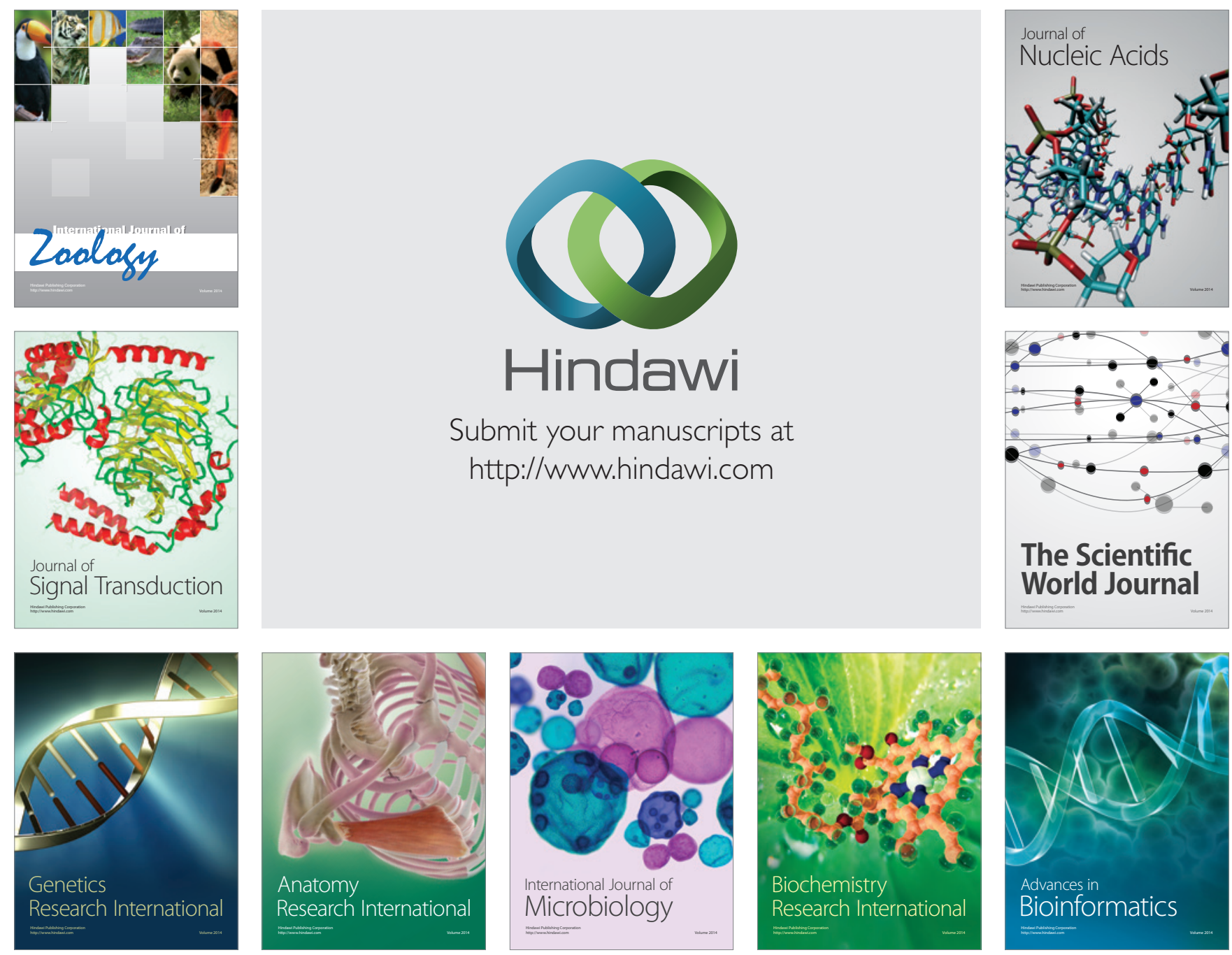

The Scientific World Journal
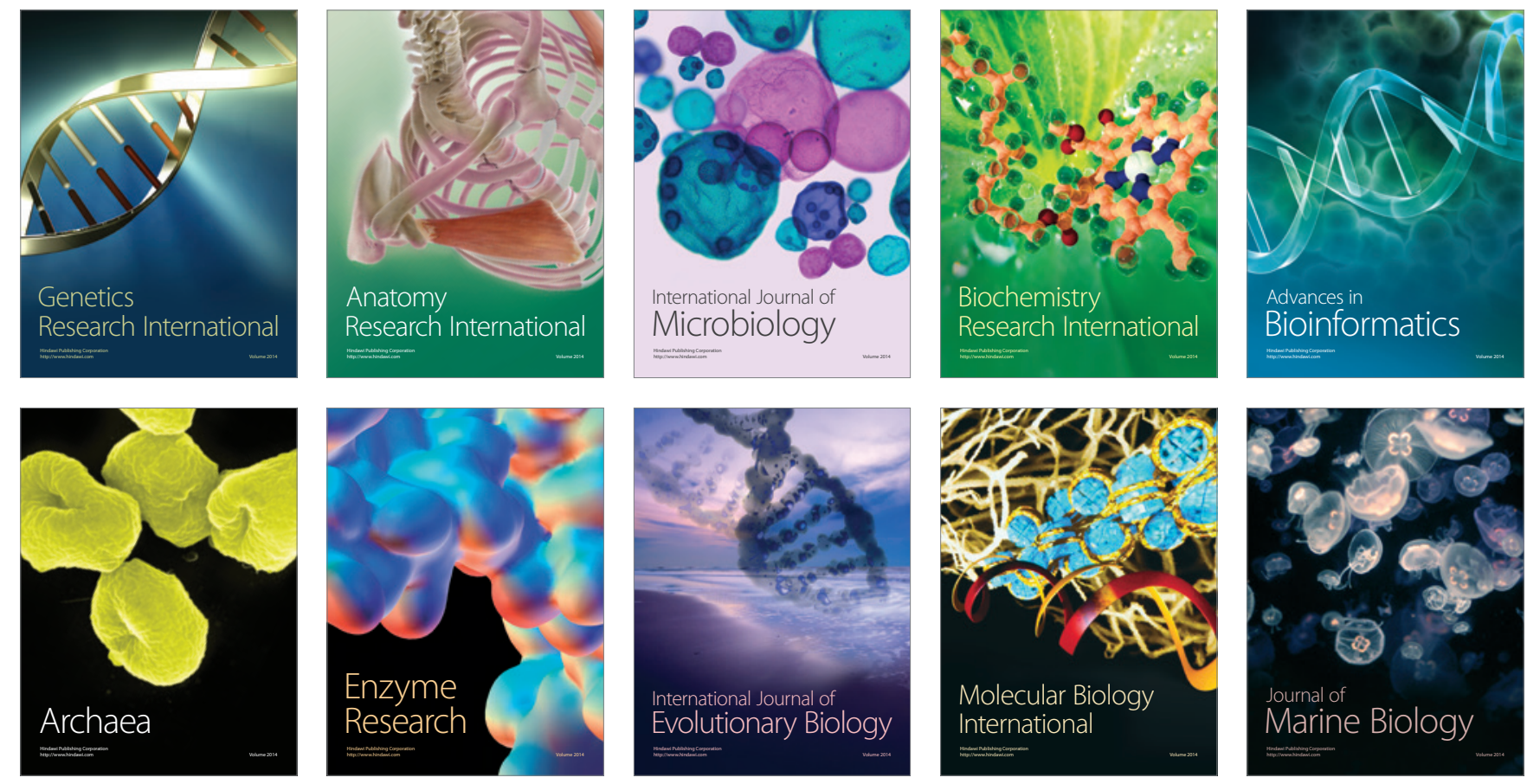